\title{
\begin{tabular}{l|l} 
Mibraries & DSpace@MIT
\end{tabular}
}

\author{
MIT Open Access Articles
}

This is a supplemental file for an item in DSpace@MIT

Item title: Visions of resilience: lessons from applying a digital democracy tool in New York's Jamaica Bay watershed Link back to the item: https://hdl.handle.net/1721.1/122823 


\section{Visions of resilience: lessons from applying a digital democracy tool in New York's Jamaica Bay watershed}

Mario A. Giampieri ${ }^{1,2^{*}}$, Bryce DuBois ${ }^{3}$, Shorna Allred ${ }^{3}$, Katherine Bunting-Howarth ${ }^{4}$, Kim

Fisher $^{1}$, Jesse Moy ${ }^{1}$ and Eric W. Sanderson ${ }^{1}$

${ }^{1}$ Wildlife Conservation Society, 2300 Southern Blvd., Bronx NY 10460.

${ }^{2}$ Massachusetts Institute of Technology, 77 Massachusetts Ave, Department of Urban Studies and Planning, Cambridge MA 02139

${ }^{3}$ Cornell University, 102 Fernow Hall, Department of Natural Resources, Ithaca NY 14853

${ }^{4}$ New York Sea Grant, 112 Rice Hall, Cornell University, Ithaca NY 14853

*corresponding author. Email: mariogiampieri@gmail.com phone: (720) 849-3434

Keywords: Visionmaker, climate adaptation, green infrastructure, urban estuary, communitybased planning

\section{ACKNOWLEDGEMENTS}

This study was supported by funding from the United States Department of the Interior, National Park Service [Cooperative agreement: P14AC01473]. Additional funding for development of Visionmaker was provided by the Rockefeller Foundation, Brooke Astor Fund for New York City Education at the New York Community Trust, and the Summit Foundation. We would also like to acknowledge and thank all the participants in the Visionmaker workshops and the support of the Science and Resilience Institute at Jamaica Bay for this effort. 


\section{ABSTRACT}

Resilience to extreme weather events and other sudden changes is an issue facing many communities in the early $21^{\text {st }}$ century. Planning to respond to disasters is particularly complicated in densely inhabited, multi-jurisdictional urban social-ecological systems like the watershed of Jamaica Bay, a large urbanized estuary on the south side of New York City. This area contains parklands managed by New York City, the National Park Service, and other agencies, four sewage treatment plants, three former landfills, and urban and suburban communities, all of which were heavily impacted by Hurricane Sandy in 2012. Here successful resilience planning and response requires participation from a wide variety of government and civil society players each with different types of knowledge, value systems, and expectations about what resilience means. To investigate how "visions" of future resilience differed among several communities living in or concerned with Jamaica Bay, New York, we deployed a free, Internet-based modeling framework called Visionmaker that enabled interactive scenario creation and testing. Through a series of standardized workshops, we recruited participants from a variety of different communities of practice (i.e. researchers, land managers, educators, nongovernmental organization staff, and community board members) to design "visions of resilience". Visions spanned terrestrial and marine environments and contained natural and built ecosystems. Most users favored increasing resilience through expanding salt marsh and green infrastructure while, for the most part, keeping the built city landscape of streets and buildings intact. We compare and contrast these visions and discuss the implications for future resilience planning in coastal cities. 


\section{INTRODUCTION}

Resilience, defined as the ability for a system to return to its previous state after a shock or disruption (Holling 1973; Walker and Salt 2006; Sanderson et al. 2016), is an issue facing many communities in a time of climate change, which almost assuredly will continue to produce more shocks and disruptions in the future. Unfortunately, past experiences with disasters including hurricanes in New Orleans and New York City, tornadoes in Joplin, Missouri, fires in the San Gabriel Mountains near Los Angeles, and devastating floods along the Mississippi and in southern Louisiana, suggest there is often a rush to "rebuild the familiar" in post-disaster response (Kates et al. 2006). Rebuilding in place to pre-storm conditions, while no doubt comforting to the people impacted, may in the long-run create further risks and the potential for even greater damages.

Recognizing the need to plan for resilience differently, a variety of high profile attempts have been made to provide information and jumpstart the innovation process. For example, in the wake of Hurricane Sandy that struck the mid-Atlantic US Coast in 2012, the US Department of Housing and Urban Development and Rockefeller Foundation launched "Rebuild by Design" (rebuildbydesign.org), commissioning ten "world-class, interdisciplinary teams" to develop "transformative planning and design approaches" after the storm. The US Army Corps of Engineers "Hurricane Sandy Coastal Management Division" has launched integrated studies to analyze strategies to promote the resiliency of the North Atlantic coast in preparation for future extreme weather (USACE 2013). The NOAA Coastal Services Center created "Digital Coast," a website (www.csc.noaa.gov/digitalcoast) designed to help people "turn data into information they can use," including county-level reports, a sea level rise and coastal flood impacts viewer, videos and a blog. 
While important and necessary, these efforts focus on traditional models of public engagement, where experts create knowledge (like flood maps) or ideas (like novel architectural designs) that are subsequently communicated to the public. The public is conceived of as recipient of information and knowledge and not a participant in knowledge creation about and design for resilience strategies (Lane et al. 2010). Researchers in public understanding of science have called into question the effectiveness of this mode of knowledge production and dissemination, especially where changes in public behavior or policy are necessary (Hegger et al. 2011; McNie 2007; Callon 1999). More effective appear to be shared, interactive modes of knowledge production, especially when dealing with complex, interdependent environmental problems, on the interface between science, society, and policy, like climate-related disasters (e.g. Seijger et al. 2013; Hegger et al. 2011; Lane et al. 2010).

Clearly the Internet opens new opportunities for joint knowledge creation that go beyond traditional models of public engagement (Wilsdon and Willis 2004). Digital mapping efforts, on top of Google Maps and web-deployed geographic information systems (like Digital Coast), offer spatially-explicit scientific information for anyone with a connection (Sullivan et al. 2009; Kingston 2007). Search engines are making scientific information easier to find, and counterintuitively, more trusted (Brossard \& Scheufele 2013), and social media has transformed the human ability to converse and network in spatially- and temporally-distributed ways (Shirky 2008). As a result new forms of networking are emerging (from Wikipedia to eBird to Occupy Sandy), with the potential for new knowledge and innovations to emerge not only from the experts, but from "the wisdom of the crowd" (sensu Surowiecki 2005).

This paper presents a cautionary tale from our experience using a new, Internet-based tool designed for ecological democracy in New York City. Visionmaker (Visionmaker.nyc) is a free, 
Internet-based forum designed to enable anyone (land managers, politicians, neighborhood residents, schoolchildren, etc.) to develop and share climate-resilient designs for their own neighborhood in New York City. Visionmaker combines social media tools, environmental modeling, scenario analysis, and geographically explicit data to support participatory processes, acknowledge needs of different stakeholders, and accrue community benefits from a transparent planning process (Adger 2003; Reed 2008). As part of this project, we developed a Jamaica Bay-focused version of Visionmaker (Visionmaker Jamaica Bay), explicitly designed to foster a robust and informed conversation about resilience, though as will be seen, a platform does not a conversation make. The overall research effort was designed to explore how different communities of practice define resilience in reference to the Jamaica Bay watershed (DuBois et al., in review). This particular paper focuses on our experiences with Visionmaker as modality to explore community defined visions of resilience. We are interested in the choices people make about the built environment, lifestyle choice, and climate scenarios, as they explore for themselves different approaches to social-ecological resilience, and whether there is any consensus about a way forward.

\section{METHODS}

\section{Study site}

Our work focuses on Jamaica Bay (centered at $40^{\circ} 36^{\prime} 14^{\prime \prime} \mathrm{N}, 073^{\circ} 50^{\prime} 07^{\prime}$ ' W), a tidal lagoon protected by the Rockaway Peninsula on the southeast side of New York City (Figure 1). Like many other urban estuaries, the boundaries of the bay and its environs before extensive urbanization were dynamic and less-defined (Buxton and Shernoff 1995; Sanderson 2016). Shifts occurred gradually, as with century-long changes in sea level, or at punctuated moments due to stochastic disturbance events, such as hurricanes or nor'easter storms (Swanson et al. 2016). 
Although human impacts on the local ecology and landscape have long been felt, from the subsistence fishing and hunting of the Lenape Native Americans through the colonial and early American agricultural period (Black 1981), it was during the twentieth century that the edges of the bay became a more industrialized and residential space. Land reclamation, waste dumping, and large-scale infrastructure development made the bay's boundaries and jurisdictions more relevant in the everyday experience of area residents. The Jamaica Bay watershed encompasses nearly half of the boroughs of Brooklyn and Queens, which had populations of nearly 2.6 million and 2.3 million, respectively, in 2014 (U.S. Census Bureau 2016b; 2016c). Meanwhile, in 1971, the management of the undeveloped interior marsh lands and waters was passed from the City of New York to the National Park Service, with a mandate "to conserve the scenery and the natural and historic objects and the wild life therein and to provide for the enjoyment of the same in such manner and by such means as will leave them unimpaired for the enjoyment of future generations." (US Congress 1916)

Hurricane Sandy reminded the public of the damage that winds, floods and storm surge from coastal storms can inflict on the nation. In Sandy's case, 159 people were killed, more than 650,000 homes were damaged or destroyed, thousands of businesses temporarily shuttered, and millions of lives were disrupted in only a few days' time (Hurricane Sandy Rebuilding Task Force 2013). The temporary closure of John F. Kennedy International Airport resulted in cancelled or delayed flights. Unfortunately, Sandy was not the first, nor the last, severe storm to threaten the region. At least four hurricanes have made direct hits on NYC over the last 400 years, while many others have made near misses (Scileppi and Donnelly 2007; Talke et al. 2014). Severe "nor'easter" storms can cause seas to rise 2.0-2.5 m and occur more frequently than hurricanes (Orton et al. 2012). Climate change predictions for NYC suggest the future will 
see increased precipitation, higher temperatures, and rising sea levels (Horton 2015a,b) for the nation's most important economic region, which contributes 9.5 percent of the nation's gross domestic product (U.S. Bureau of Economic Analysis 2013) and houses 1 in 16 Americans (U.S Census 2016a).

\section{Description of Visionmaker}

Visionmaker is a web-based tool that serves as a means for anyone with an internet connection to explore how changes to the built environment, lifestyle choices, and climate scenarios could affect the environmental performance of an area of interest. It is focused on the geography of all five boroughs of New York City including the waters of the upper and lower harbor, the Hudson and East Rivers, and Jamaica Bay. Users are presented with maps on a $10 \mathrm{~m}$ grid showing the city in terms of 70 "ecosystems". Ecosystems can be terrestrial or marine; and built or natural. Ecosystems include building types, transportation infrastructure, utilities of various kinds, and managed open space, as well as more natural, indigenous ones (forests, wetlands, etc.). A distinction is also made between "base" ecosystems that entirely fill a cell and allow no other base ecosystem type (e.g. a cell is either a building or a lawn or a forest) and "modifier" ecosystems, that can be placed on or below other ecosystems, modifying their characteristics (e.g. a green roof modifies a building, a bike lane modifies a street, an eelgrass meadow modifies shallow estuary). Users are presented a version of the historical ecosystems of New York City at the time of European Contact from the Welikia Project (welikia.org), which builds on the Mannahatta Project (Sanderson 2009) alongside ecosystems for the contemporary city in 2014.

Using Visionmaker, users create concepts or "visions" by first choosing a bounded area of interest. Vision extents are selected by aggregating city blocks, with blocks created by dividing along the street-center line. For parts of the city where there are no streets (e.g. in natural areas 
and in the estuary waters), approximations of blocks are created using paths, islands, or other convenient geographic boundaries. The minimum size of a vision is one block. Users also have the option of attributing a year they want their vision to represent (i.e. what year are you imagining?).

Visions are constructed of three inputs beside the geographic boundaries: ecosystems, lifestyle choices, and climate scenarios. Ecosystems are of two types: base ecosystems, of which there can be only one type per 33-square-foot $\left(10 \mathrm{~m}^{2}\right)$ cell, and modifiers, of which there can be multiple types per cell. Base ecosystems refer to the main use type of the cell, including buildings, transportation types, or natural ecosystems. Modifiers change the ecosystem parameters of the cell, but do not replace the base ecosystem. For example, a green roof changes the biomass and water-holding capacity of an apartment building, but does not change the amount of floor area available for residential use. Similarly, street trees, bike lanes, trails in a forest, and piers in an estuary all model modifications, but not wholescale changes, to ecosystems.

Lifestyle choice options are made up of consumption and waste production parameterizations for average American, average New Yorker, average earthling, average Lenape person—a Native American, representing a semihorticultural lifestyle as existed in the pre-colonial New York City landscape - and an environmentally conscious, "eco-hipster" lifestyle. The selected lifestyle choice determines how metrics including transportation choices, household size, and residential density are modeled within the vision area. Climate scenarios draw on work from the New York City Panel on Climate Change (Horton et al. 2015a,b) and include past climate (ca. 1609), present climate (ca. 2010), and future climate scenarios for 2020, 2050, 2080, and 2100. Visionmaker calculates metrics of environmental performance to compare the user's vision with 
the current condition based on modern geographic data describing the city today and historical condition based on the Welikia Project (Sanderson 2009; see also welikia.org). Current models include a storm-event precipitation and runoff model (the "water" model); an energy, transportation, and ecosystem carbon cycling model (the "carbon" model); a species habitat and diversity model (the "biodiversity" model); a residential and worker model (the "population" model); and costs of demolition and construction (the "economics" model), all of which are explained briefly below. After a period of editing and revision, users may then choose to share their visions with selected others or with the public at large. Users may also issue "challenges" in terms of vision metrics.

Visionmaker's water calculations are based on a simple, flow-through storm event model, based on methods adapted from Vörösmarty et al. (1989), Vörösmarty et al. (1996) and Mitchell et al. (2001). The water flow calculations depend on the ecosystems, lifestyle, and climate scenarios selected by the user and are calculated across the entire vision extent. Unlike the other models (i.e. geography, population, carbon and biodiversity), which simulate annual estimates, the water model is based on storm events that occur on a single day in June. Combined sewer flows are based on piped water demand and stormwater flows. Piped water demand depends on lifestyles and ecosystems. It is estimated on a per capita basis for residents using the residential water consumption rate parameter and on a per area basis for other use cases (e.g. office, retail, public assembly, etc.) based on the use water consumption rate density parameter, and adjusted for "gray water recycling" modifier. Stormwater flows are based on the amount of precipitation that falls on pervious and impervious surfaces. Some of the water infiltrates (which can be modified for impervious surfaces with green roofs, bioswales, and rain barrel/cistern modifiers) and some 
is evaporated; the rest is assumed to flow into the city's stormwater system. Additional details are available in Sanderson et al. (2016) and at visionmaker.nyc.

Visionmaker's carbon model estimates annual fuel consumption by first estimating energy demand for seven different fuel uses: heating, cooling, cooking, lighting \& appliances, transporting people (i.e. personal transportation), transporting stuff (i.e. freight), making electricity, making steam, and using grid electricity. Energy consumption is satisfied by consumption of different fuel types using a combination of ecosystem- and lifestyle-dependent parameters. Fuel consumption is adjusted for energy losses during conversion of the fuel into the energy source through energy efficiency parameters. Consumption of individual fuels is summed across uses, converted into carbon dioxide and methane emissions using fuel specific emission rates. User changes to the built environment and lifestyle choices are reflected assuming the same technologies and efficiencies for which there was data when the models were parameterized; no assumptions are made as to emergent levels of efficiency or their future availability. Additional details are available in Sanderson et al. (2016) and at visionmaker.nyc. Visionmaker's biodiversity model estimates areas of generic habitat types from the areas of ecosystems. Most natural ecosystems become equivalent habitat types; most built ecosystems (buildings, roads, utilities) are combined into a general "pavement and buildings" habitat type. The habitat area reported below excludes "pavement and buildings." Finally, Visionmaker's population model estimates the number of residents based on a lifestyle dependent residential use area density parameter and the estimated floor areas of the different ecosystem types allocated to residential uses. Additional details are available in Sanderson et al. (2016) and at visionmaker.nyc. 


\section{Communities of practice}

We purposively sampled participants representing five communities of practice (COPs) in the Jamaica Bay watershed area. Wenger (1999) defines communities of practice as”...groups of people who share a concern or passion for something they do and learn how to do it better as they interact regularly." The domain of a community of practice can vary and formal 'expertise' is not a prerequisite. Rather, COPs share a domain of interest that group members make some form of commitment to and therefore have some competence in. A second dimension is the community. The defining feature of a community is that members interact and learn together although they may work separately and interact at different levels of frequency. Finally, practice defines members as practitioners that share a repertoire of resources. That is, COPs share stories, tools, and other information with each other that they use in their work. We settled on five communities of practice that we thought, given that they have different approaches, represent different subsets of the watershed population that have different understandings of what resilience means - community board members, non-governmental organization employees, public agency officials, researchers, and K-12 educators.

Potential participants were identified using a snowball sampling methodology, whereby we identified key "champions" in each community of practice and asked them to share a flyer about the workshops with their network and/or to provide us with contact information (Patton 2001). We also attended community events, or analogous events (e.g. research conferences, land manager meetings), and handed out flyers and advertised the workshops. We created a Facebook page and used that to post information about upcoming workshops on key organization public pages. Finally, we posted workshop information on the websites of the Science and Resilience Institute at Jamaica Bay (SRIJB), the Metropolitan Waterfront Alliance and other partner 
organizations, with requests for redistribution. Each flyer had a list of workshop dates, by COP, as well as information about the workshops and a link to sign up online. When participants signed up online they were sent a thank you email with a link to a pre-workshop survey. The workshops took place under the umbrella of SRIJB, which is a research institute that seeks to produce integrated knowledge in order to increase biodiversity, well-being, and adaptive capacity in coastal communities and waters surrounding Jamaica Bay and New York City and had an existing network of relationships with individuals across communities of practice (“Science \& Resilience Institute," 2017).

\section{Visionmaker workshops}

From July 2015 - April 2016 we held 13 workshops in the communities around Jamaica Bay or in nearby locations directed toward people interested in Jamaica Bay from five "communities of practice": primary and secondary school teachers, researchers, land managers, staff or affiliates of environmental non-governmental organizations, and community board members (Appendix 4). On average six people attended each workshop (6.7 mean; 5.66 SD). Each workshop was conducted in the same way by the same people (authors Giampieri and DuBois.) Participants were asked to fill out pre-workshop surveys with basic demographic information and to assess their previous knowledge of climate change effects and resilience planning either on-line before the workshop or at the beginning of the workshop; the survey instruments received previous approval from the Cornell University Institutional Review Board. At the workshop, participants were given short presentations about different kinds of disturbances to the estuary system, the Science and Resilience Institute at Jamaica Bay (SRIJB) and the Visionmaker project and goals (Online Resource 1). They were then given a brief tutorial on using Visionmaker. With this background, they were given 45-75 minutes to create a vision of what resilience for Jamaica Bay 
means to them. Participants were asked to bring laptops for use at workshops, and several laptops were provided, but in some cases participants shared laptops or made visions in small teams. Afterwards they discussed their visions through a moderated discussion and filled out a post-workshop survey instrument, discussed in Dubois et al. (in review). Each participant was given a unique identifier that enabled us to connect the survey results with their vision.

Workshops included a total of eighty-nine attendees, of which seventy-six completed the presurvey, fifty-five completed the post-survey, with thirty-nine matched pairs in that sample. Out of this sample, fifty-three provided vision descriptions.

\section{Vision data}

Each vision represented choices made by users regarding (1) focal geography within the Jamaica Bay watershed (hereafter, the "vision extent"), (2) climate scenario, (3) lifestyle choice, and (4) ecosystem composition. Visions were given a unique code that enabled us to connect vision responses to individual survey respondents, but all data were analyzed anonymously. We accessed vision data results from Visionmaker and conducted all analyses using Python, including the Pandas data analysis library, and Matplotlib, a statistical graphing library.

\section{RESULTS}

\section{Participants}

Over the course of thirteen workshops, we attracted 87 participants, who produced 46 non-empty visions of resilience for Jamaica Bay, or a successful completion rate of 53\%. As reported elsewhere (DuBois et al., in review) we had participants drawn from five communities of practice, including 21 NGO affiliates, 15 public agency staff, 19 researchers, 17 from community boards and 15 K-12 educators. Based on surveys before the workshop, participants were all 
adults, predominantly female (58 out of 76), inclusive of people between 18 and over 65 years of age (largest age group, 35-44 years old), well-educated (14+33+15 / 65 had a college degree, and $33+15$ / 65 had a graduate degree), most described themselves as liberal or very liberal $(31+14$ / 62). Nearly all had experienced extreme weather (59/67) or climate change (58/62), although only 38\% (25/65) reported formal resilience training. Only about half (55-37/55) lived within the Jamaica Bay watershed. Because there were no large differences between the pre- and postsurvey results among participants from the different communities of practice, and because of the low overall sample size, we combined visions across communities of practice for further analysis. Although initially intending to compare visions of resilience across communities of practice, we instead treated visions created by the entire participant population as one unit of analysis because of the relatively small sample size (DuBois et al., in review) and focused instead on specific themes and tendencies that were elicited with Visionmaker.

Table 1. Subset of five largest and five smallest visions and modifications in terms of base ecosystems, modifiers, and marine and terrestrial ecosystems (Full table available in Appendix 1)

\begin{tabular}{|c|cccc|ccccc|}
\hline & \multicolumn{3}{|c|}{ Vision extent } & \multicolumn{5}{c|}{ Vision changes } \\
\cline { 2 - 9 } $\begin{array}{c}\text { Vision } \\
\text { ID }\end{array}$ & $\begin{array}{c}\text { Area } \\
\text { (ha) }\end{array}$ & $\begin{array}{c}\text { Modifier } \\
\text { Area (ha) }\end{array}$ & $\begin{array}{c}\text { Terrestrial } \\
(\%)\end{array}$ & $\begin{array}{c}\text { Built } \\
(\%)\end{array}$ & $\begin{array}{c}\text { Base } \\
\text { Ecosystem } \\
\text { Change (\%) }\end{array}$ & $\begin{array}{c}\text { Modifier } \\
\text { Change } \\
(\%)\end{array}$ & $\begin{array}{c}\text { Terrestrial } \\
\text { Change } \\
(\%)\end{array}$ & $\begin{array}{c}\text { Marine } \\
\text { Chang } \\
\text { e (\%) }\end{array}$ & $\begin{array}{c}\text { Built } \\
\text { chan } \\
\text { ge } \\
(\%)\end{array}$ \\
\hline 16473 & 989.8 & 0.1 & 12 & 0 & 14 & 0 & 12 & 16 & 0 \\
21546 & 896.2 & 25.7 & 97 & 36 & 0 & 0 & 0 & 0 & 0 \\
19628 & 887.0 & 8.8 & 18 & 12 & 8 & $<1$ & 9 & 7 & 8 \\
16477 & 863.5 & 1.5 & 11 & 0 & $<1$ & 0 & $<1$ & $<1$ & 0 \\
16479 & 665.4 & 2.9 & $<1$ & 1 & 0 & 0 & 0 & 0 & 0 \\
19532 & 7.9 & 0.1 & 100 & 94 & 0 & 0 & 0 & 0 & 0
\end{tabular}




\begin{tabular}{|c|cccc|ccccc|}
19630 & 7.1 & 0.4 & 100 & 79 & 15 & $<1$ & 15 & 15 & 11 \\
19566 & 2.6 & 0.1 & 100 & 80 & 0 & 8 & 13 & 0 & 7 \\
19478 & 2.4 & 0.1 & 97 & 89 & 95 & 2 & 139 & 52 & 85 \\
21543 & 1.5 & 0.0 & 100 & 78 & 0 & 14 & 0 & 0 & 14 \\
\hline
\end{tabular}

\section{Vision extent, year, climate scenario and lifestyle choice}

Participants created visions that varied from 1.5 - 990 ha in extent, with the mean vision area of 198 ha ( $\mathrm{SD}=282$ ha) (Figure 1; Table 1). For comparison, a block on Manhattan Island is approximately 2.26 ha, so visions ranged from a single block to an area equivalent to approximately 100 blocks on Manhattan. Most visions were in the Jamaica Bay watershed or adjacent areas of Coney Island (where some of the workshops were held).

Three-quarters of visions (76\%; 36 of 46) were terrestrially focused with extents more than $75 \%$ on land (Table 1; Appendix 1). Most vision extents included both built and natural ecosystems; 15 visions were created in areas that were $75 \%$ or more built; an additional 11 in extents that were $50-75 \%$ built; 8 that were $25-50 \%$ built; and 8 between $0-25 \%$ built. Three visions were created entirely in natural ecosystems.

Participants attributed a variety of different years to their visions. The most common year that participants imagined in the future was 2050 (17 of 46 visions); the second most common was 2020 (11 out of 46). Only two visions were attributed to past 2050; the longest range was a single vision attributed to 2100. Three visions were backdated (one to 2012, when Hurricane Sandy hit, and two to 2014.) 
Participants nearly all chose the average New Yorker lifestyle (40 of 46 visions), which is also the default. Four visions were constructed using the "Eco-conscious" lifestyle, two with the Lenape lifestyle, and one with the Average American lifestyle.

Participants mainly chose the baseline climate (1970 - 2010) (31 out of 46 visions), which is also the default; 6 chose the 2020 climate scenario, 5 the 2050 climate scenario, and only 1 the 2080 climate scenario. Four visions were attributed to the past climate reconstruction from 1609.

For use in the water model, participants can also select a precipitation event. Most participants retained the default selection of "Showers" (38 out of 46 visions). All the other visions chose more severe precipitation events: rainy day (1), thunderstorm (3), and severe storm (5). The exact definitions of these precipitation events depend on the climate scenario selection.

2. Top ten most modified Visionmaker base ecosystems and frequency of changes (full table available in Appendix 2)

\begin{tabular}{|l|l|l|l|l|l|}
\hline & Ecosystem & $\begin{array}{l}\text { Visions with } \\
\text { change to } \\
\text { this } \\
\text { Terrestrial } \\
\text { / Marine } \\
(\%)\end{array}$ & $\begin{array}{l}\text { Number of } \\
\text { visions with } \\
\text { change }\end{array}$ & $\begin{array}{l}\text { Number of } \\
\text { visions with } \\
\text { reduction in } \\
\text { ecosystem } \\
\text { area }\end{array}$ & $\begin{array}{l}\text { Number of visions } \\
\text { with gain in } \\
\text { ecosystem area }\end{array}$ \\
\hline Pavement (other) & terrestrial & 54 & 25 & 25 & 0 \\
\hline Sidewalk & terrestrial & 52 & 24 & 24 & 0 \\
\hline Street (collector) & terrestrial & 48 & 22 & 22 & 4 \\
\hline Ornamental garden & terrestrial & 46 & 21 & 20 & 2 \\
\hline Park savanna & terrestrial & 43 & 20 & 16 & 18 \\
\hline Shallow estuary & marine & 43 & 20 & & \\
\hline
\end{tabular}




\begin{tabular}{|l|l|r|r|r|r|}
\hline Lawn & terrestrial & 37 & 17 & 17 & 0 \\
\hline Disturbed Land & terrestrial & 35 & 16 & 16 & 0 \\
\hline High salt marsh & marine & 35 & 16 & 0 & 16 \\
\hline Boulevard (arterial) & terrestrial & 33 & 15 & 14 & 1 \\
\hline
\end{tabular}

\section{Vision ecosystem composition}

Participants changed the base ecosystems in less than half ( 20 of the 46 visions); another 11

visions changed only modifier ecosystems, which left 16 visions without any ecosystem changes

at all. (Visions could be composed of only lifestyle or climate scenario changes, of course.)

The most commonly changed ecosystems, of those visions that changed a base ecosystem, were sidewalks and "pavement (other)" category, which represents pedestrian plazas, alleys, driveways, and other paved surface that are not dedicated roadways (2; Appendix 2). More than half of the visions included an alteration in one of these two ecosystems; in all cases the change was to reduce the area of these paved types in favor of pervious landcover, particularly along the shoreline. Similarly, nearly half of visions altered collector streets, ornamental gardens, lawns and park savannas (which are lawns with scattered trees, as in a park), mainly by decreasing them in favor of gains in high and low salt marsh and agricultural fields (which we interpret as desire for increased community gardening space).

Table 3. Top ten most modified modifier ecosystems in visions of resilience for Jamaica Bay (full table available in Appendix 3)

\begin{tabular}{|l|l|l|l|l|l|}
\hline & & $\begin{array}{l}\text { Visions with } \\
\text { Ecosystem }\end{array}$ & $\begin{array}{l}\text { Number } \\
\text { of visions } \\
\text { with } \\
\text { change }\end{array}$ & $\begin{array}{l}\begin{array}{l}\text { Number of } \\
\text { visions with } \\
\text { reduction in } \\
\text { ecosystem } \\
\text { area }\end{array} \\
\text { change to this } \\
\text { ecosystem }(\%)\end{array}$ & $\begin{array}{l}\text { Number of visions } \\
\text { with gain in } \\
\text { ecosystem area }\end{array}$ \\
\hline
\end{tabular}




\begin{tabular}{|l|l|r|r|r|r|}
\hline Green roof & terrestrial & 33 & 15 & 1 & 14 \\
\hline Street trees & terrestrial & 30 & 14 & 8 & 6 \\
\hline Bike lane & terrestrial & 26 & 12 & 7 & 5 \\
\hline Pier & marine & 17 & 8 & 7 & 1 \\
\hline Cistern / rain barrels & terrestrial & 15 & 7 & 1 & 6 \\
\hline Photovoltaic panels & terrestrial & 13 & 6 & 1 & 4 \\
\hline Bioswale & terrestrial & 9 & 4 & 0 & 4 \\
\hline Stream & terrestrial & 9 & 4 & 0 & 3 \\
\hline Compost bin & terrestrial & 7 & 3 & 0 & 3 \\
\hline Solar heating panels & terrestrial & 7 & 3 & 0 & 4 \\
\hline
\end{tabular}

In terms of modifier ecosystems, the most commonly altered modifier were green roofs, followed closely by street trees and bike lanes (Table 3; Appendix 3). While most users were in favor of increased green roofs, adding them where they are not currently present, the changes made to street trees included both increases and decreases. The decreases in street trees may have been unintentional consequences to modification of paved ecosystems (as above) and the users not restoring "street trees" that had been eliminated. In some visions, users also eliminated piers, a kind of hardscape, and added cisterns/water barrels, photovoltaic panels, bioswales, and streams (Appendix 3).

\section{Vision ecosystem metrics}

Visions of Jamaica Bay resilience slightly increased greenhouse gas emissions, reduced combined sewer flows, increased the area of habitat, and decreased the residential population, on average, although there was wide variation (Table 4.) Changes were calculated on a percentage 
basis comparing the user vision to the same area in the city today. Note that the most extreme changes in ecosystem metrics came from a vision that made wholescale changes to a neighborhood, returning it to natural ecosystem types, which decreased the population, decreased the stormwater flows, and dramatically increased the amount of habitat. Most other visions were much more conservative in terms of ecosystem change and overall extent of the vision (as above), and therefore generated much smaller changes in metric values.

Table 4. Percentage change in ecosystem metrics estimated by Visionmaker, comparing Jamaica Bay visions to the same areas of New York City in 2014.

\begin{tabular}{|l|r|r|r|r|}
\hline & \multicolumn{4}{|l|}{$\begin{array}{l}\text { Percentage changes in metrics calculated for } \\
\text { Jamaica Bay visions relative to the same areas } \\
\text { in New York City in 2014 }\end{array}$} \\
\hline & Mean & $\begin{array}{l}\text { Standard } \\
\text { Deviation }\end{array}$ & Minimum & Maximum \\
\hline $\begin{array}{l}\text { Greenhouse gas } \\
\text { emissions }\end{array}$ & $2 \%$ & $40 \%$ & $-87 \%$ & $174 \%$ \\
\hline $\begin{array}{l}\text { Combined sewer } \\
\text { flows }\end{array}$ & $-11 \%$ & $34 \%$ & $-100 \%$ & $107 \%$ \\
\hline Area of habitat & $31 \%$ & $97 \%$ & $-22 \%$ & $519 \%$ \\
\hline Residential population & $-8 \%$ & $32 \%$ & $-100 \%$ & $35 \%$ \\
\hline
\end{tabular}

\section{DISCUSSION}

\section{Conservative nature of visions}

Despite the ability of Visionmaker to support the design of and assess the ecosystem conditions of practically any vision of the future, most users were quite conservative in visions they made. Participants approached the exercise by focusing on relatively short-term (i.e. within their lifetimes) and relatively small-scale changes. Most visions covered only tiny proportions of the watershed, on the order of about 10 city blocks. This result was unexpected, given the magnitude 
of issues Jamaica Bay faces, and is a potentially significant finding for others pursuing resilience plans in an urban context.

Not surprisingly, participants that lived within the watershed tended to create visions for areas in their own neighborhood, expressing a close relationship between where they lived and where they imagined. Participants who lived outside the watershed almost always created visions directly adjacent to or including the shoreline and nearshore waters, rarely reaching far into the surrounding urbanized matrix. $78 \%$ of all visions included or were adjacent to the shoreline, suggesting that participants approached resiliency planning as something that takes place at or along the coast. Of the visions that did abut or include the shoreline, half (18/36) added salt marsh to the shoreline in efforts to soften the shore edge. Of the remaining eighteen visions that include but do not soften the shoreline, ten did not include ecosystem changes of any kind on the shore, but rather made interventions further inland. These changes range from adding vegetable gardens to more residential area. These visions did not necessarily address resilience to extreme weather events directly, instead focusing on other place-specific issues (i.e. new schools, more housing) or improving environmental performance in general.

Another indication of conservativism in visionmaking is that none of the visions were made in the water or marshlands east of Cross-Bay Boulevard or at John F. Kennedy Airport (Figure 1), despite the importance of these areas for resilience of human and natural communities. While this geographic bias toward the western part of Jamaica Bay may be a sampling artifact, participants may also have viewed the airport as inflexible and difficult to change, given its economic importance. Or perhaps they believed that other actors will address the airport, so it is not of community concern. 
Participants largely adhered to the existing street grid, limiting their ecosystem modifications to coastal areas or other open spaces, suggesting a desire to engender resilient response while staying within what is deemed as pragmatic and least disruptive. When viewed alongside the relatively near-term scope of overall visions, it becomes apparent that participants favored incremental changes that could be achieved within their lifetimes. This tendency was made clearer by the generally small, conservative adaptations, essentially maintaining the status quo in the face of a disturbance event and despite personal experiences (reported in the workshop surveys) of personal experience with Hurricane Sandy or knowledge of resilience practice (DuBois et al., in review).

Participants made more changes to modifier ecosystems (as opposed to base ecosystems), further displaying a preference for making minor non-invasive modifications to existing built forms as opposed to proposing new forms. The reliance on modifiers, and particularly green roofs, signals a tendency to prefer localized interventions as opposed to district- or system-wide changes. Participants generally expressed the desire to improve environmental performance and quality of live overall within their vision extent.

The small-scale and specificity of visions may be a result of the recognition that larger-scale interventions are expensive and politically problematic, especially in an urban environment. All New Yorkers are aware of the tangle of financial, regulatory, and social forces working to maintain the status quo. It is also possible that they could be a result of the workshop process. Given other constraints related to timing, venue and attracting participants (see below), we could not provide more than two hours for vision-making (though the platform was available over the Internet for additional use outside the workshop hours.) Time constraints may have limited the imaginative scope of visions made by volunteers. While users generally seemed interested in 
exploring resilience relative to a specific place (i.e. where they live or work), as opposed to positioning that place in relation to the larger watershed, we might also interpret the changes they did make as policy preferences to be adopted on larger scales.

\section{Limitations in participation}

A critical element of implementing a tool like Visionmaker is participation; it doesn't work if only a few people play. Despite considerable efforts to advertise the workshops and to work through local community groups to encourage participation, the showing at the Visionmaker workshops was much less than desired or anticipated. We expected that the nature of the tool, focused on the neighborhoods where people live and work, would increase interest in its application (Manzo \& Perkins 2016). We anticipated that place-based interventions, in an experimental framework driven by their own questions, would be more successful than generalized discussions (Manzo \& Perkins 2016).

For those people who did attend the workshops, another problem was incompletion of the visions. Approximately $45 \%$ of the attendees did not complete a vision during the workshop period, despite on-line and printed helping aids, and two or more skilled users at each workshop. This suggests that either the two-hour workshop was too short to successfully build enough skills with the platform, or that the current presentation is too complex or abstruse to be easily understood, despite considerable efforts to design a transparent and attractive interface. Additionally, our results are consistent with construal level theory (CLT) which posits that the level of psychological distance impacts the level of abstract or concrete thinking individuals have about a target (Trope and Liberman 2010). Spatial distance (e.g. physical space) is one of four dimensions of psychological distance; the other types of distance are temporal (time), social (interpersonal), and hypothetical (an unlikely or future oriented event). Thus, people think 
abstractly and have a high level of construal at larger spatial scales and are able to think much more concretely at smaller geographic and time scales as the psychological distance is lowered and so is their level of construal. Theory would indicate that in situations of high construal, people are less likely to focus on the big picture of a situation and more likely to focus on the present in great detail, which is what we found with the preponderance of visions focusing on shorter time scales and smaller geographic areas (Trope and Liberman 2010). Rather, the visions reflected concrete thinking about spaces and places that were familiar to participants, which lowered the psychological distance. Climate change concern can be increased by making "potential climate impacts relevant to individual's social group, locality, and lifetime" (Spence et al. 2012, p. 13).

Perhaps the greatest difficulty is that Visionmaker is a new innovation: it is not the typical mode of interaction around urban planning issues. The standard for urban planning outreach in the New York City context consists of presentations made by city agencies, architects or developers, of plans they have drawn up, followed by periods for public comment. Many critical decisions about where and how interventions will occur are taken in controlled settings within agencies. Academic studies of scenarios of resilience are conveyed through scientific publications and presentations, often to other academics. The model of engagement presented here- offering a tool for people to design and evaluate novel scenarios informed by scientific models - does not fit these traditional cases.

\section{Areas for future research and improvement}

The Visionmaker platform has proven to be an effective design tool for prototyping different scenarios; however, it is a complex tool that requires participants to be somewhat familiar with 
web-based GIS tools to be able to express nuanced visions of resilience. Future studies should include more time for training and engagement with the tool to allow participants to engage meaningfully.

Oftentimes participants expressed qualitative ideas for pursuing resilience or stances on certain interventions that were expressed during workshops. Some participants were able to articulate those thoughts spatially using the Visionmaker platform in the time given, but others had difficulty doing so. Future experiments combining non-spatial identification of preferred interventions (i.e. better transportation, more flood protection, more access to agricultural land, etc.) followed by spatial visioning could allow participants to organize their intervention strategy and produce more articulate visions.

The workshops were open ended to the point that some participants did not have time to determine a specific problem to respond to, much less respond to it. A more guided visioning session (perhaps determined to some extent by participant interest) could help frame the experience and produce more robust visions. Alternatively, future experiments could begin by presenting an explicit scenario to participants (i.e. sea level is predicted to rise by $\mathrm{x}$ inches over the next $\mathrm{x}$ years) and asking them to respond to that scenario.

Many, although not all, participants chose the default settings for climate and lifestyle scenarios, while a few explored more long-term or more extreme options. This raises the question of whether the implication of or ability to change the defaults are clear to users. Presumably participants familiar with extreme weather events understood that climate and precipitation events factor into questions of resilience, but the effects of lifestyle choices may have been less clear. Others may have been more focused on articulating the physical interventions they envisioned, and did not consider lifestyle or climate selections for lack of time or experience 
with the tool. Future visioning workshops should be formatted so that users are required to align the stated year of their vision with the climate scenario option, deliberately considering the time scale of their vision (relative to other, perhaps more distant options) and the fact that climate is changing and will affect their designs. This guided deliberation will not only help participants focus their vision-making process, but will also make the results more accurately reflect the intended vision.

\section{REFERENCES}

Adger, W.N., 2003. Social Capital, Collective Action, and Adaptation to Climate Change.

Economic Geography 79, 387-404. doi:10.1111/j.1944-8287.2003.tb00220.x

Black, F.R., 1981. Jamaica Bay: A History (Cultural Resource Management Study No. 3). Gateway National Recreation Area, National Park Service, Washington, D.C.

Brossard, D., Scheufele, D.A., 2013. Science, New Media, and the Public. Science 339, 40-41. doi:10.1126/science.1232329

Buxton, H.T., Shernoff, P.K., 1995. Ground-water resources of Kings and Queens Counties, Long Island, New York (No. Open-File Report 92-76). U.S. Geological Survey, Albany, NY.

Callon, M., 1999. The Role of Lay People in the Production and Dissemination of Scientific Knowledge. Science Technology Society 4, 81-94. doi:10.1177/097172189900400106

Dubois, B., Allred, S., Sanderson, E., Giampieri, M. and K. Bunting-Howarth. (In Review). Participatory Resilience Visioning of the Jamaica Bay Watershed. Society and Natural Resources.

Hegger, D., Lamers, M., Van Zeijl-Rozema, A., Dieperink, C., 2012. Conceptualising joint knowledge production in regional climate change adaptation projects: success conditions and 
levers for action. Environmental Science \& Policy 18, 52-65.

doi:10.1016/j.envsci.2012.01.002

Horton, R., Bader, D., Kushnir, Y., Little, C., Blake, R., Rosenzweig, C., 2015a. New York City Panel on Climate Change 2015 Report Chapter 1: Climate Observations and Projections. Ann. N.Y. Acad. Sci. 1336, 18-35. doi:10.1111/nyas.12586

Horton, R., Little, C., Gornitz, V., Bader, D., Oppenheimer, M., 2015b. New York City Panel on Climate Change 2015 Report Chapter 2: Sea Level Rise and Coastal Storms. Ann. N.Y. Acad. Sci. 1336, 36-44. doi:10.1111/nyas.12593

Holling, C.S., 1973. Resilience and Stability of Ecological Systems. Annual Review of Ecology and Systematics 4, 1-23. doi:10.1146/annurev.es.04.110173.000245

Hurricane Sandy Rebuilding Task Force, 2013. Hurricane Sandy Rebuilding Strategy: Stronger Communities, A Resilient Region. U.S. Department of Housing and Urban Development, Washington D.C.

Kates, R.W., Colten, C.E., Laska, S., Leatherman, S.P., 2006. Reconstruction of New Orleans after Hurricane Katrina: A research perspective. Proceedings of the National Academy of Sciences 103, 14653-14660. doi:10.1073/pnas.0605726103

Kingston, R., 2007. Public Participation in Local Policy Decision-making: The Role of Webbased Mapping. The Cartographic Journal, 44, 138-144. doi:10.1179/000870407X213459

Lane, S.N., Odoni, N., Landström, C., Whatmore, S.J., Ward, N., Bradley, S., 2011. Doing flood risk science differently: an experiment in radical scientific method. Transactions of the Institute of British Geographers 36, 15-36. doi:10.1111/j.1475-5661.2010.00410.x 
Manzo, L.C., Perkins, D.D., 2016. Finding Common Ground: The Importance of Place Attachment to Community Participation and Planning. Journal of Planning Literature 20, 335-350. doi:10.1177/0885412205286160

McNie, E.C., 2007. Reconciling the supply of scientific information with user demands: an analysis of the problem and review of the literature. Environmental Science \& Policy 10, 1738. doi:10.1016/j.envsci.2006.10.004

Mitchell, V.G., Mein, R.G., McMahon, T.A., 2001. Modelling the urban water cycle. Environmental Modelling \& Software 16, 615-629. doi:10.1016/S1364-8152(01)00029-9

Orton, P., Georgas, N., Blumberg, A., Pullen, J., 2012. Detailed modeling of recent severe storm tides in estuaries of the New York City region. J. Geophys. Res. 117, C09030. doi:10.1029/2012JC008220

Patton, M.Q. 2001. Qualitative Research and Evaluation Methods,..3 ${ }^{\text {rd }}$ edition. Sage Publications.

Reed, M.S., 2008. Stakeholder participation for environmental management: A literature review. Biological Conservation 141, 2417-2431. doi:10.1016/j.biocon.2008.07.014

Sanderson, E.W., 2009. Mannahatta: A Natural History of New York City. Abrams, New York. Sanderson, E.W., 2016. Cartographic Evidence for Historical Geomorphological Change and Wetland Formation in Jamaica Bay, New York. Northeastern Naturalist 23, 277-304.

Sanderson, E.W., Solecki, W.D., Waldman, J.R., Parris, A. (Eds.), 2016. Prospects for Resilience: Insights from New York City’s Jamaica Bay. Island Press, Washington D.C. Science \& Resilience Institute [WWW Document], 2017. URL http://www.srijb.org/ 
Scileppi, E., Donnelly, J.P., 2007. Sedimentary evidence of hurricane strikes in western Long Island, New York. Geochemistry, Geophysics, Geosystems 8, n/a-n/a. doi:10.1029/2006GC001463

Seijger, C., Dewulf, G., Otter, H., Van Tatenhove, J., 2013. Understanding interactive knowledge development in coastal projects. Environmental Science \& Policy 29, 103-114. doi:10.1016/j.envsci.2013.02.007

Shirky, C., 2008. Here comes everybody: the power of organizing without organizations. Penguin Press, New York.

Spence, A., Poortinga, W., Pidgeon, N. 2012. The psychological distance of climate change. Risk Analysis 32(6): 957-972.

Sullivan, B.L., Wood, C.L., Iliff, M.J., Bonney, R.E., Fink, D., Kelling, S., 2009. eBird: A citizen-based bird observation network in the biological sciences. Biological Conservation 142, 2282-2292. doi:10.1016/j.biocon.2009.05.006

Surowiecki, J., 2005. The wisdom of crowds. Anchor Books, New York.

Talke, S.A., Orton, P., Jay, D.A., 2014. Increasing Storm Tides in New York Harbor, 1844-2013. Geophys. Res. Lett. 2014GL059574. doi:10.1002/2014GL059574

Trope, Y. and N. Liberman. 2010. Construal-level theory of psychological distance. Psychological Review 117(2): 440-463.

U.S. Army Corps of Engineers, 2013. Rockaway Beach, Queens, NY. Restoration of Previously Constructed Projects (Fact Sheet). U.S. Army Corps of Engineers, New York.

U.S. Bureau of Labor Statistics, 2013. New York-White Plains-Wayne, NY-NJ Metropolitan Division - May 2013 OES Metropolitan and Nonmetropolitan Area Occupational Employment and Wage Estimates. U.S. Department of Commerce, Washington D.C. 
U. S. Census Bureau, 2016. Metropolitan and Micropolitan Statistical Areas Available at: http://www.census.gov/population/metro/ (accessed 2.10.17).

U.S. Census Bureau, Population Estimates Program, 2016. QuickFacts - Kings County (Brooklyn Borough), New York. Available at: http://www.census.gov/quickfacts/table/AGE115210/36047 (accessed 2.15.17).

U.S. Census Bureau, Population Estimates Program, 2016. QuickFacts - Queens County (Queens Borough), New York. URL http://www.census.gov/quickfacts/table/AGE115210/36081

U.S. Congress, 1916. Organic Act of 1916. Text available online: https://www.nps.gov/grba/learn/management/organic-act-of-1916.htm (accessed 2.10.17).

Vorösmarty, C.J., Moore, B., Grace, A.L., 1989. Continental scale models of water balance and fluvial transport: an application to South America. Global Biogeochemical Cycles 3, 241265.

Vorösmarty, C.J.., Willmott, C.J., Choudhury, B.J.., Schloss, A.L., Stearn, T.K., Robeson, S.M.., Dorman, T.J., 1996. Analyzing the discharge regime of a large tropical river through remote sensing, ground-based climatic data, and modeling. WATER RESOURCES RESEARCH $32,3137-3150$.

Walker, B., Salt, D., 2006. Resilience Thinking: Sustaining Ecosystems and People in a Changing World. Island Press, Washington, DC.

Wenger, E., 1999. Communities of Practice: Learning, Meaning, and Identity, 1 edition. ed. Cambridge University Press, Cambridge, U.K.; New York, N.Y.

Wilsdon, J., Willis, R., 2004. See-through Science: Why Public Engagement Needs to Move Upstream. Demos, Washington, DC 
Appendix 1. Visions and modifications in terms of base ecosystems, modifiers, and marine and terrestrial ecosystems

\begin{tabular}{|c|c|c|c|c|c|c|c|c|c|}
\hline \multirow[b]{2}{*}{$\begin{array}{l}\text { Vision } \\
\text { ID }\end{array}$} & \multicolumn{4}{|c|}{ Vision extent } & \multicolumn{5}{|c|}{ Vision changes } \\
\hline & Area (ha) & $\begin{array}{c}\text { Modifier } \\
\text { Area } \\
\text { (ha) }\end{array}$ & $\begin{array}{c}\text { Terrestrial } \\
(\%)\end{array}$ & $\begin{array}{l}\text { Built } \\
(\%)\end{array}$ & $\begin{array}{c}\text { Base } \\
\text { Ecosystem } \\
\text { Change } \\
(\%)\end{array}$ & $\begin{array}{c}\text { Modifier } \\
\text { Change } \\
(\%)\end{array}$ & $\begin{array}{c}\text { Terrestrial } \\
\text { Change } \\
(\%)\end{array}$ & $\begin{array}{c}\text { Marine } \\
\text { Change } \\
(\%)\end{array}$ & $\begin{array}{c}\text { Built } \\
\text { change } \\
(\%)\end{array}$ \\
\hline 16473 & 989.8 & 0.1 & 12 & 0 & 14 & 0 & 12 & 16 & 0 \\
\hline 21546 & 896.2 & 25.7 & 97 & 36 & 0 & 0 & 0 & 0 & 0 \\
\hline 19628 & 887.0 & 8.8 & 18 & 12 & 8 & $<1$ & 9 & 7 & 8 \\
\hline 16477 & 863.5 & 1.5 & 11 & 0 & $<1$ & 0 & $<1$ & $<1$ & 0 \\
\hline 16479 & 665.4 & 2.9 & $<1$ & 1 & 0 & 0 & 0 & 0 & 0 \\
\hline 21544 & 525.3 & 7.2 & 12 & 11 & 1 & $<1$ & 1 & $<1$ & 1 \\
\hline 21542 & 506.5 & 5.8 & 9 & 6 & $<1$ & 1 & 1 & $<1$ & 1 \\
\hline 21545 & 496.1 & 27.7 & 99 & 87 & 0 & $<1$ & 0 & 0 & $<1$ \\
\hline 19627 & 493.5 & 5.2 & 7 & 4 & 2 & $<1$ & 2 & 2 & 1 \\
\hline 19561 & 459.3 & 2.9 & 98 & 34 & 9 & $<1$ & 18 & $<1$ & 12 \\
\hline 19559 & 459.3 & 2.9 & 98 & 34 & 0 & 0 & 0 & 0 & 0 \\
\hline 19535 & 222.7 & 3.3 & 100 & 85 & 1 & 2 & 2 & $<1$ & 3 \\
\hline
\end{tabular}




\begin{tabular}{|c|c|c|c|c|c|c|c|c|c|}
\hline 19625 & 186.2 & 14.6 & 78 & 66 & 1 & $<1$ & 1 & 2 & 1 \\
\hline 16472 & 164.0 & 3.5 & 96 & 33 & 8 & $<1$ & 10 & 6 & 5 \\
\hline 19557 & 120.6 & 5.6 & 59 & 11 & 0 & 0 & 0 & 0 & 0 \\
\hline 16487 & 108.4 & 0.8 & 1 & 2 & 2 & 0 & $<1$ & 3 & 0 \\
\hline 16475 & 107.1 & 0.0 & 85 & $<1$ & 0 & 0 & 0 & 0 & 0 \\
\hline 17154 & 105.1 & 7.4 & 5 & 11 & $<1$ & 0 & $<1$ & $<1$ & $<1$ \\
\hline 19549 & 103.7 & 6.1 & 98 & 73 & 4 & 6 & 7 & 1 & 3 \\
\hline 20792 & 69.6 & 2.2 & 95 & 64 & 0 & 4 & 4 & 0 & 7 \\
\hline 20789 & 65.6 & 1.0 & 100 & 65 & 0 & 4 & 3 & 0 & 6 \\
\hline 19538 & 64.5 & 2.7 & 97 & 58 & 0 & 24 & 0 & 0 & 24 \\
\hline 16474 & 53.9 & 5.6 & 78 & 79 & 10 & $<1$ & 10 & 11 & 9 \\
\hline 16471 & 50.3 & 0.1 & 95 & 36 & 0 & 0 & 2 & 0 & $<1$ \\
\hline 19534 & 45.0 & 2.9 & 93 & 50 & 2 & 34 & 3 & 1 & 12 \\
\hline 19560 & 42.3 & 1.0 & 99 & 87 & 35 & 10 & 59 & 12 & 46 \\
\hline 19555 & 35.0 & 5.5 & 100 & 99 & 0 & 25 & 24 & 0 & 46 \\
\hline 17152 & 32.7 & 0.0 & 95 & 0 & 0 & 0 & 0 & 0 & 0 \\
\hline 19479 & 32.1 & 0.4 & 100 & 71 & 100 & 4 & 169 & 31 & 71 \\
\hline 20788 & 29.8 & 1.0 & 97 & 39 & 0 & 0 & 0 & 0 & 0 \\
\hline
\end{tabular}




\begin{tabular}{|c|cccc|ccccc|}
20790 & 28.3 & 0.5 & 91 & 61 & 15 & 14 & 25 & 5 & 23 \\
22722 & 24.8 & 4.3 & 100 & 100 & 0 & $<1$ & 3 & 0 & 2 \\
19567 & 24.6 & 0.2 & 98 & 78 & 0 & 0 & 0 & 0 & 0 \\
19480 & 23.8 & 0.0 & 81 & 40 & 29 & 0 & 37 & 22 & 26 \\
19565 & 23.3 & 1.4 & 100 & 84 & 0 & 0 & 0 & 0 & 0 \\
20791 & 23.3 & 0.1 & 95 & 45 & 0 & 0 & 0 & 0 & 0 \\
19473 & 20.2 & 1.1 & 100 & 94 & 34 & 4 & 53 & 14 & 35 \\
21550 & 20.0 & 1.3 & 99 & 63 & 0 & 1 & 3 & 0 & 3 \\
19533 & 16.2 & 0.3 & 95 & 64 & 34 & 1 & 33 & 35 & 21 \\
19537 & 15.7 & 0.3 & 100 & 73 & 0 & 18 & 6 & 0 & 13 \\
16478 & 13.5 & 1.3 & 100 & 91 & 0 & 55 & 0 & 0 & 0 \\
19532 & 7.9 & 0.1 & 100 & 94 & 0 & 0 & 0 & 0 & 0 \\
19630 & 7.1 & 0.4 & 100 & 79 & 15 & $<1$ & 15 & 15 & 11 \\
19566 & 2.6 & 0.1 & 100 & 80 & 0 & 8 & 13 & 0 & 7 \\
19478 & 2.4 & 0.1 & 97 & 89 & 95 & 2 & 139 & 52 & 85 \\
21543 & 1.5 & 0.0 & 100 & 78 & 0 & 14 & 0 & 0 & 14 \\
\hline
\end{tabular}


Appendix 2. Modifications to base ecosystems and frequency of changes

\begin{tabular}{|c|c|c|c|c|c|}
\hline Ecosystem & $\begin{array}{l}\text { Terrestrial } \\
\text { / Marine }\end{array}$ & $\begin{array}{l}\text { Visions } \\
\text { with } \\
\text { change to } \\
\text { this } \\
\text { ecosystem } \\
(\%)\end{array}$ & $\begin{array}{l}\text { Number } \\
\text { of } \\
\text { visions } \\
\text { with } \\
\text { change }\end{array}$ & $\begin{array}{l}\text { Number } \\
\text { of visions } \\
\text { with } \\
\text { reduction } \\
\text { in } \\
\text { ecosystem } \\
\text { area }\end{array}$ & $\begin{array}{l}\text { Number } \\
\text { of visions } \\
\text { with gain } \\
\text { in } \\
\text { ecosystem } \\
\text { area }\end{array}$ \\
\hline Pavement (other) & terrestrial & 54 & 25 & 25 & 0 \\
\hline Sidewalk & terrestrial & 52 & 24 & 24 & 0 \\
\hline Street (collector) & terrestrial & 48 & 22 & 22 & 0 \\
\hline Ornamental garden & terrestrial & 46 & 21 & 20 & 1 \\
\hline Park savanna & terrestrial & 43 & 20 & 16 & 4 \\
\hline Shallow estuary & marine & 43 & 20 & 18 & 2 \\
\hline Lawn & terrestrial & 37 & 17 & 17 & 0 \\
\hline Disturbed Land & terrestrial & 35 & 16 & 16 & 0 \\
\hline High salt marsh & marine & 35 & 16 & 0 & 16 \\
\hline Boulevard (arterial) & terrestrial & 33 & 15 & 14 & 1 \\
\hline Parking lot & terrestrial & 33 & 15 & 14 & 1 \\
\hline Low salt marsh & marine & 33 & 15 & 2 & 13 \\
\hline
\end{tabular}




\begin{tabular}{|c|c|c|c|c|c|}
\hline Apartment building & terrestrial & 30 & 14 & 12 & 2 \\
\hline Garage & terrestrial & 26 & 12 & 11 & 1 \\
\hline Beach & terrestrial & 24 & 11 & 8 & 3 \\
\hline Single family home & terrestrial & 24 & 11 & 11 & 0 \\
\hline Agricultural field & terrestrial & 22 & 10 & 2 & 8 \\
\hline Public assembly hall & terrestrial & 22 & 10 & 8 & 2 \\
\hline Shrub land & terrestrial & 22 & 10 & 5 & 5 \\
\hline Deep water estuary & marine & 20 & 9 & 8 & 1 \\
\hline Conifer forest & terrestrial & 17 & 8 & 7 & 1 \\
\hline Freshwater marsh & terrestrial & 13 & 6 & 2 & 4 \\
\hline Mixed use: retail / residential building & terrestrial & 13 & 6 & 3 & 3 \\
\hline Paved ball field/court & terrestrial & 13 & 6 & 5 & 1 \\
\hline Pond & terrestrial & 13 & 6 & 2 & 4 \\
\hline Retail building & terrestrial & 13 & 6 & 5 & 1 \\
\hline School or university & terrestrial & 13 & 6 & 3 & 3 \\
\hline Traffic slowed street & terrestrial & 13 & 6 & 6 & 0 \\
\hline Warehouse & terrestrial & 13 & 6 & 5 & 1 \\
\hline
\end{tabular}




\begin{tabular}{|c|c|c|c|c|c|}
\hline Derelict structures & terrestrial & 11 & 5 & 5 & 0 \\
\hline Oak hickory forest & terrestrial & 11 & 5 & 0 & 5 \\
\hline Office building & terrestrial & 11 & 5 & 4 & 1 \\
\hline Solar energy facility & terrestrial & 11 & 5 & 0 & 5 \\
\hline Tidal energy facility & terrestrial & 11 & 5 & 0 & 5 \\
\hline Factory & terrestrial & 9 & 4 & 4 & 0 \\
\hline Greenhouse / vertical farm & terrestrial & 9 & 4 & 0 & 4 \\
\hline Hardwood swamp & terrestrial & 9 & 4 & 1 & 3 \\
\hline Meadow & terrestrial & 9 & 4 & 2 & 2 \\
\hline $\begin{array}{l}\text { Mixed use: restaurant / residential } \\
\text { building }\end{array}$ & terrestrial & 9 & 4 & 1 & 3 \\
\hline Gas station & terrestrial & 7 & 3 & 3 & 0 \\
\hline Mixed use: restaurant / retail building & terrestrial & 7 & 3 & 2 & 1 \\
\hline Orchard & terrestrial & 7 & 3 & 0 & 3 \\
\hline Sewage treatment plant & terrestrial & 7 & 3 & 2 & 1 \\
\hline Cottages / Mobile home & terrestrial & 4 & 2 & 1 & 1 \\
\hline Highway & terrestrial & 4 & 2 & 2 & 0 \\
\hline Hospital & terrestrial & 4 & 2 & 2 & 0 \\
\hline
\end{tabular}




\begin{tabular}{|c|c|c|c|c|c|}
\hline $\begin{array}{l}\text { Mixed use: office / residential } \\
\text { building }\end{array}$ & terrestrial & 4 & 2 & 0 & 2 \\
\hline Swimming pool & terrestrial & 4 & 2 & 1 & 1 \\
\hline Utility yard & terrestrial & 4 & 2 & 2 & 0 \\
\hline Wind farm & terrestrial & 4 & 2 & 0 & 2 \\
\hline Airfield & terrestrial & 2 & 1 & 1 & 0 \\
\hline Camp & terrestrial & 2 & 1 & 0 & 1 \\
\hline Cliffs and rock outcrops & terrestrial & 2 & 1 & 0 & 1 \\
\hline Computer data center & terrestrial & 2 & 1 & 0 & 1 \\
\hline Heavy rail line & terrestrial & 2 & 1 & 1 & 0 \\
\hline Hotel & terrestrial & 2 & 1 & 1 & 0 \\
\hline Light rail line & terrestrial & 2 & 1 & 0 & 1 \\
\hline $\begin{array}{l}\text { Mixed use: restaurant / office } \\
\text { building }\end{array}$ & terrestrial & 2 & 1 & 0 & 1 \\
\hline Mixed use: retail / office building & terrestrial & 2 & 1 & 1 & 0 \\
\hline Natural gas power plant & terrestrial & 2 & 1 & 0 & 1 \\
\hline Restaurant & terrestrial & 2 & 1 & 0 & 1 \\
\hline Stadium & terrestrial & 2 & 1 & 1 & 0 \\
\hline
\end{tabular}




\begin{tabular}{|c|c|c|c|c|c|}
\hline Waste energy power plant & terrestrial & 2 & 1 & 0 & 1 \\
\hline Water treatment plant & terrestrial & 2 & 1 & 0 & 1 \\
\hline Water/wastewater storage tank & terrestrial & 2 & 1 & 1 & 0 \\
\hline Airport terminal & terrestrial & 0 & 0 & 0 & 0 \\
\hline Alley & terrestrial & 0 & 0 & 0 & 0 \\
\hline Cemetery & terrestrial & 0 & 0 & 0 & 0 \\
\hline Cogeneration plant & terrestrial & 0 & 0 & 0 & 0 \\
\hline Diesel power plant & terrestrial & 0 & 0 & 0 & 0 \\
\hline Elevated train & terrestrial & 0 & 0 & 0 & 0 \\
\hline Fuel storage tank & terrestrial & 0 & 0 & 0 & 0 \\
\hline Landfill & terrestrial & 0 & 0 & 0 & 0 \\
\hline Restaurant/Office & terrestrial & 0 & 0 & 0 & 0 \\
\hline Restaurant/Residential & terrestrial & 0 & 0 & 0 & 0 \\
\hline Restaurant/Retail & terrestrial & 0 & 0 & 0 & 0 \\
\hline Solid waste transfer plant & terrestrial & 0 & 0 & 0 & 0 \\
\hline
\end{tabular}


Appendix 3. Modifications to modifier ecosystems in visions of resilience for Jamaica

\begin{tabular}{|c|c|c|c|c|c|}
\hline Ecosystem & $\begin{array}{l}\text { Terrestrial } \\
\text { / Marine }\end{array}$ & $\begin{array}{l}\text { Visions } \\
\text { with } \\
\text { change to } \\
\text { this } \\
\text { ecosystem } \\
(\%)\end{array}$ & $\begin{array}{l}\text { Number } \\
\text { of } \\
\text { visions } \\
\text { with } \\
\text { change }\end{array}$ & $\begin{array}{l}\text { Number } \\
\text { of visions } \\
\text { with } \\
\text { reduction } \\
\text { in } \\
\text { ecosystem } \\
\text { area }\end{array}$ & $\begin{array}{l}\text { Number } \\
\text { of visions } \\
\text { with gain } \\
\text { in } \\
\text { ecosystem } \\
\text { area }\end{array}$ \\
\hline Green roof & terrestrial & 33 & 15 & 1 & 14 \\
\hline Street trees & terrestrial & 30 & 14 & 8 & 6 \\
\hline Bike lane & terrestrial & 26 & 12 & 7 & 5 \\
\hline Pier & marine & 17 & 8 & 7 & 1 \\
\hline Cistern / rain barrels & terrestrial & 15 & 7 & 1 & 6 \\
\hline Photovoltaic panels & terrestrial & 13 & 6 & 1 & 5 \\
\hline Bioswale & terrestrial & 9 & 4 & 0 & 4 \\
\hline Stream & terrestrial & 9 & 4 & 0 & 4 \\
\hline Compost bin & terrestrial & 7 & 3 & 0 & 3 \\
\hline Solar heating panels & terrestrial & 7 & 3 & 0 & 3 \\
\hline Trail & terrestrial & 4 & 2 & 0 & 2 \\
\hline Graywater recycling & terrestrial & 2 & 1 & 0 & 1 \\
\hline
\end{tabular}




\begin{tabular}{|l|l|r|r|r|r|}
\hline Pedestrian bridge & terrestrial & 2 & 1 & 0 & 1 \\
\hline Permeable pavers & terrestrial & 2 & 1 & 0 & 1 \\
\hline Bridge & marine & 2 & 1 & 1 & 0 \\
\hline Subway & terrestrial & 2 & 1 & 1 & 0 \\
\hline Geothermal pump & terrestrial & 0 & 0 & 0 & 0 \\
\hline Streetcar line & terrestrial & 0 & 0 & 0 & 0 \\
\hline Eelgrass meadow & marine & 0 & 0 & 0 & 0 \\
\hline Tunnel & marine & 0 & 0 & 0 & 0 \\
\hline
\end{tabular}

Appendix 4. Workshop Dates and Locations

\begin{tabular}{|l|l|l|}
\hline Workshop Date & Workshop Location & Number of Attendees \\
\hline $11 / 03 / 2015,12-2$ PM & $\begin{array}{l}\text { New York Aquarium } \\
\text { 602 Surf Ave, Brooklyn, NY 11224 }\end{array}$ & 0 \\
\hline $11 / 04 / 2015,7-9$ PM & $\begin{array}{l}\text { Knights of Columbus } \\
\text { 333 Beach 90 } \\
\text { Beach, NY } 11693\end{array}$ & 0 \\
\hline $11 / 05 / 2015,9-11$ AM & $\begin{array}{l}\text { The CUNY Graduate Center } \\
365 \text { 5th Ave, New York, NY 10016 }\end{array}$ & 16 \\
\hline $12 / 05 / 2015,10-12$ PM & $\begin{array}{l}\text { Salt Marsh Nature Center: 3301 } \\
\text { Avenue U, Brooklyn, NY 11234 }\end{array}$ & 5 \\
\hline
\end{tabular}




\begin{tabular}{|l|l|l|}
\hline $01 / 28 / 2016,6: 30-8: 30$ PM & $\begin{array}{l}\text { Jamaica Bay Wildlife Refuge: } \\
\text { Broad Channel, NY 11693 }\end{array}$ & 7 \\
\hline $01 / 29 / 2016,1-3$ PM & $\begin{array}{l}\text { The CUNY Graduate Center } \\
\text { 365 5th Ave, New York, NY 10016 }\end{array}$ & 6 \\
\hline $01 / 30 / 2016,2-4$ PM & New York Hall of Sciences. & 17 \\
\hline $02 / 01 / 2015,12-2$ PM & $\begin{array}{l}\text { New York Aquarium: 602 Surf } \\
\text { Ave, Brooklyn, NY 11224 }\end{array}$ & 1 \\
\hline $02 / 02 / 2016,10-12$ PM & $\begin{array}{l}\text { Central Park Zoo Board Room: } \\
\text { 64th St and 5th Ave, New York, } \\
\text { NY 10021 }\end{array}$ & 6 \\
\hline $03 / 13 / 2016,11-1$ PM & $\begin{array}{l}\text { Arverne View Community Room } \\
57-17 \text { Shore Front Pkwy, Arverne, } \\
\text { NY 11692 }\end{array}$ & 4 \\
\hline $03 / 26 / 2016,12-2$ PM & $\begin{array}{l}\text { Coney Island Library - 1901 } \\
\text { Mermaid Ave, Brooklyn, NY } \\
11224\end{array}$ & 11 \\
\hline $04 / 16 / 2016,3: 00-4: 00$ PM & $\begin{array}{l}\text { Stuyvesant High School, 345 } \\
\text { Chambers St, New York, NY } \\
10282 .\end{array}$ & $\begin{array}{l}\text { SCONYC conference } \\
\text { registrants) }\end{array}$ \\
\hline $04 / 26 / 2016,7-9$ PM & $\begin{array}{l}\text { Community Board 17 (primarily } \\
\text { education committee) }\end{array}$ & 13 \\
\hline
\end{tabular}


Figure 1.

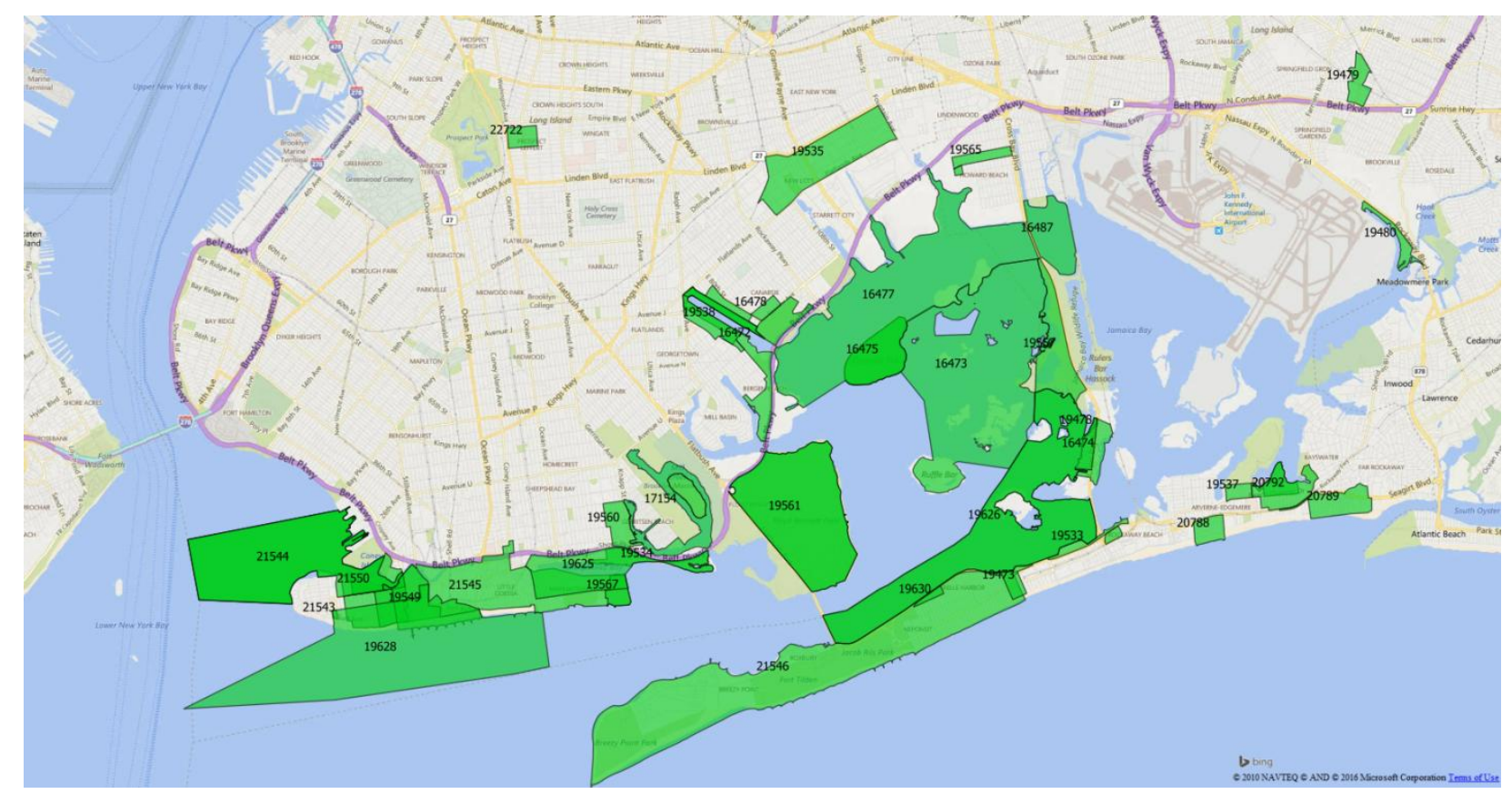

Figure 2a. 


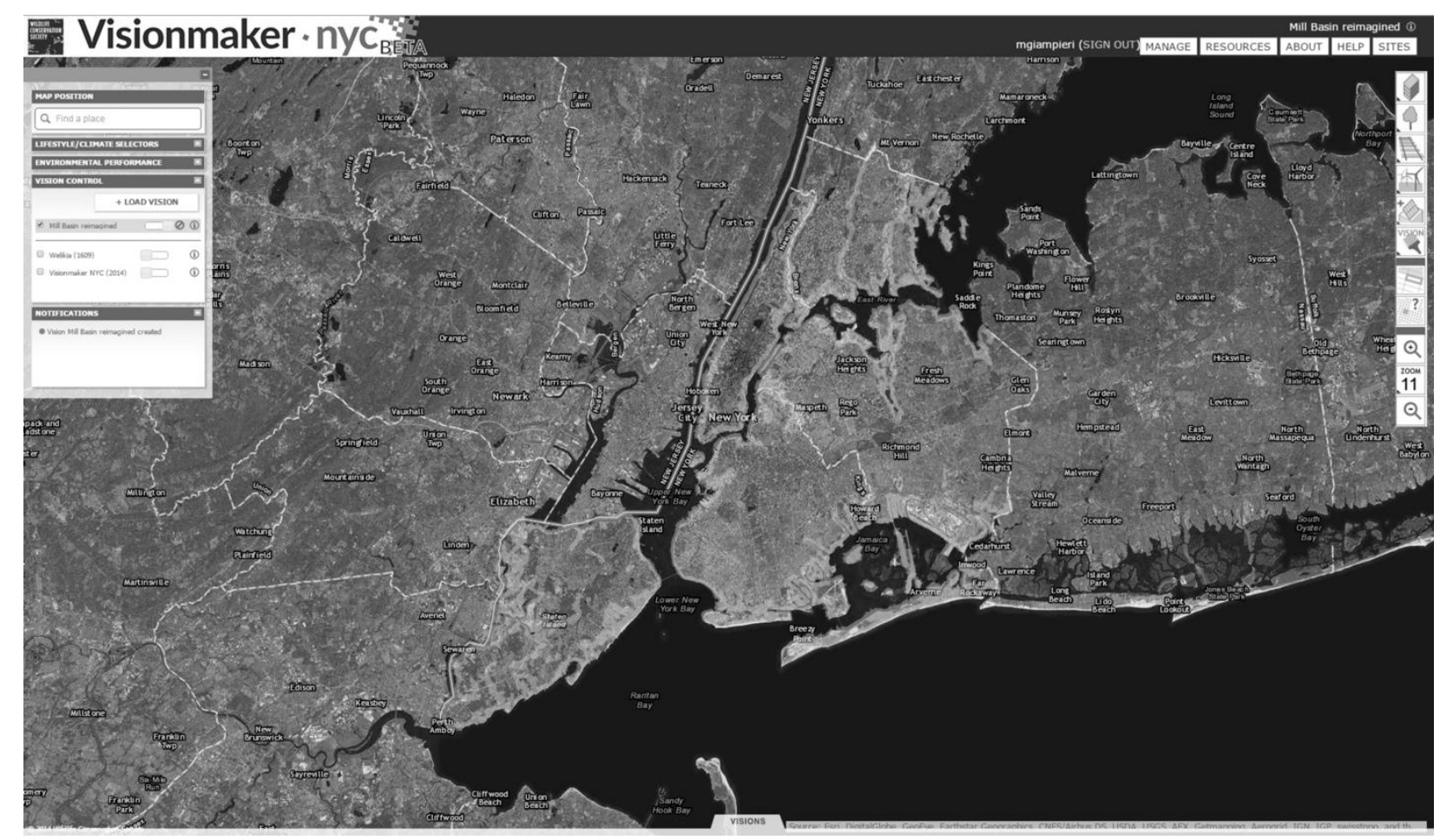

Figure $2 b$. 


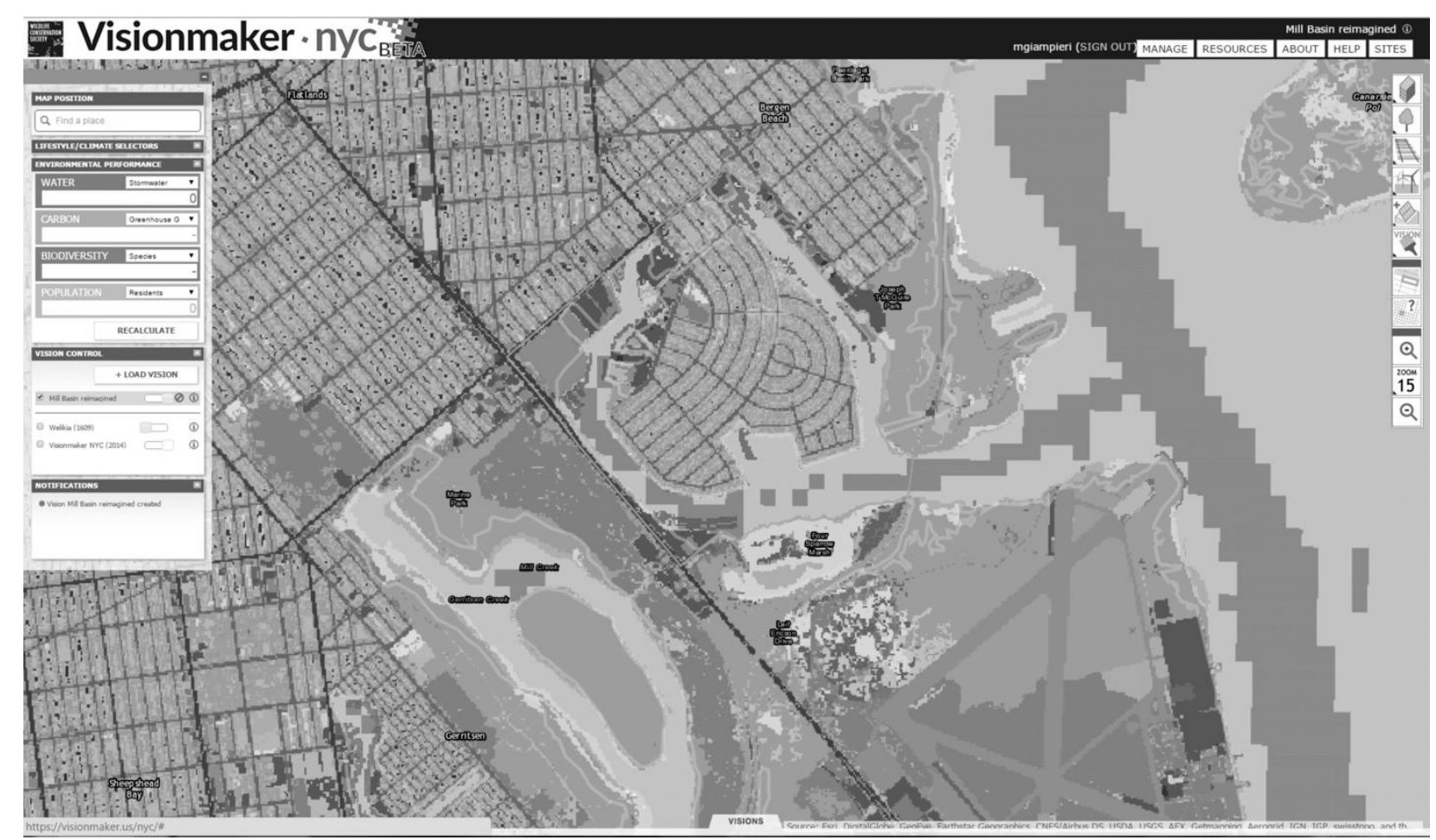

Figure 2c. 


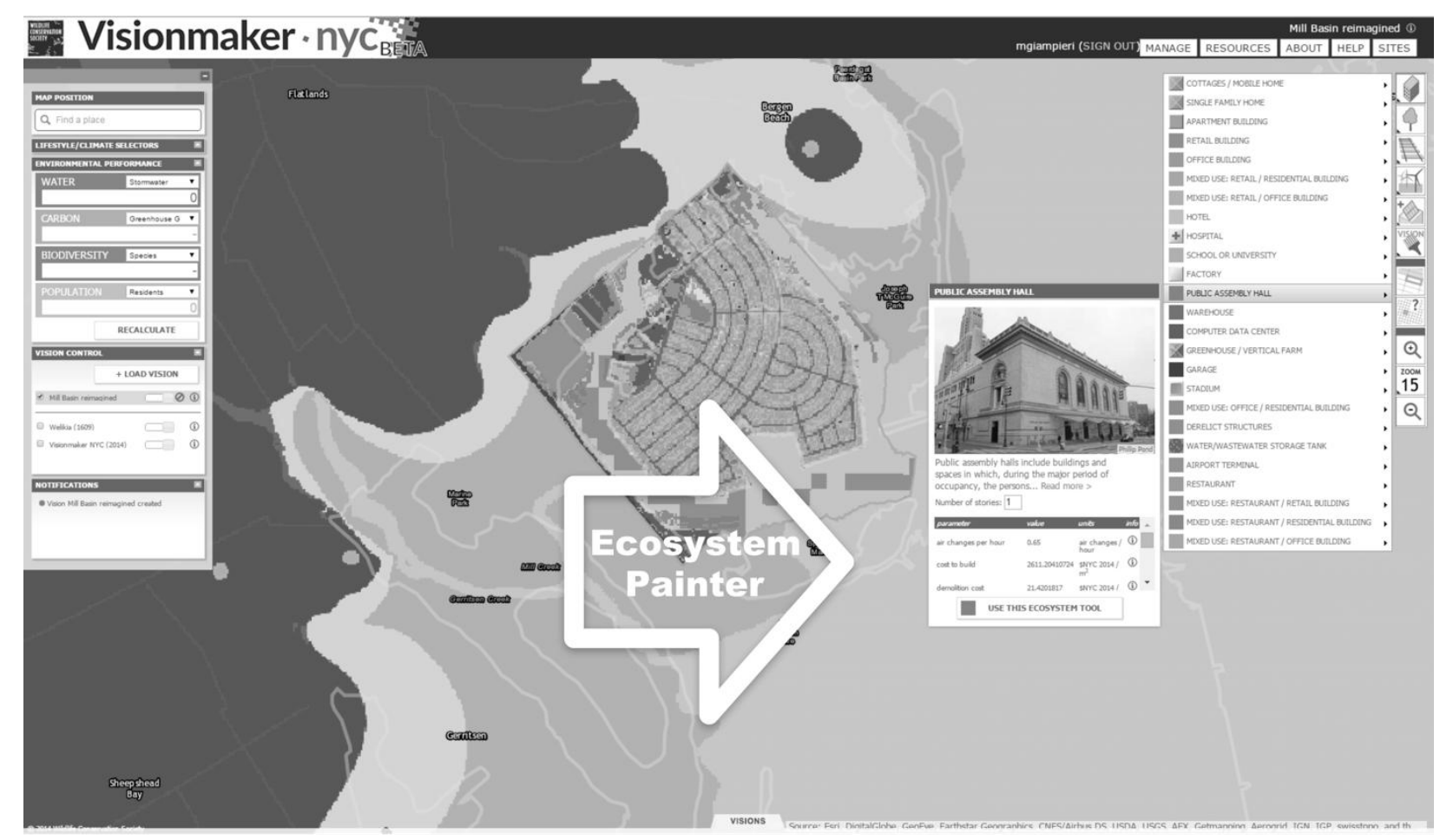

Figure $2 \mathrm{~d}$. 


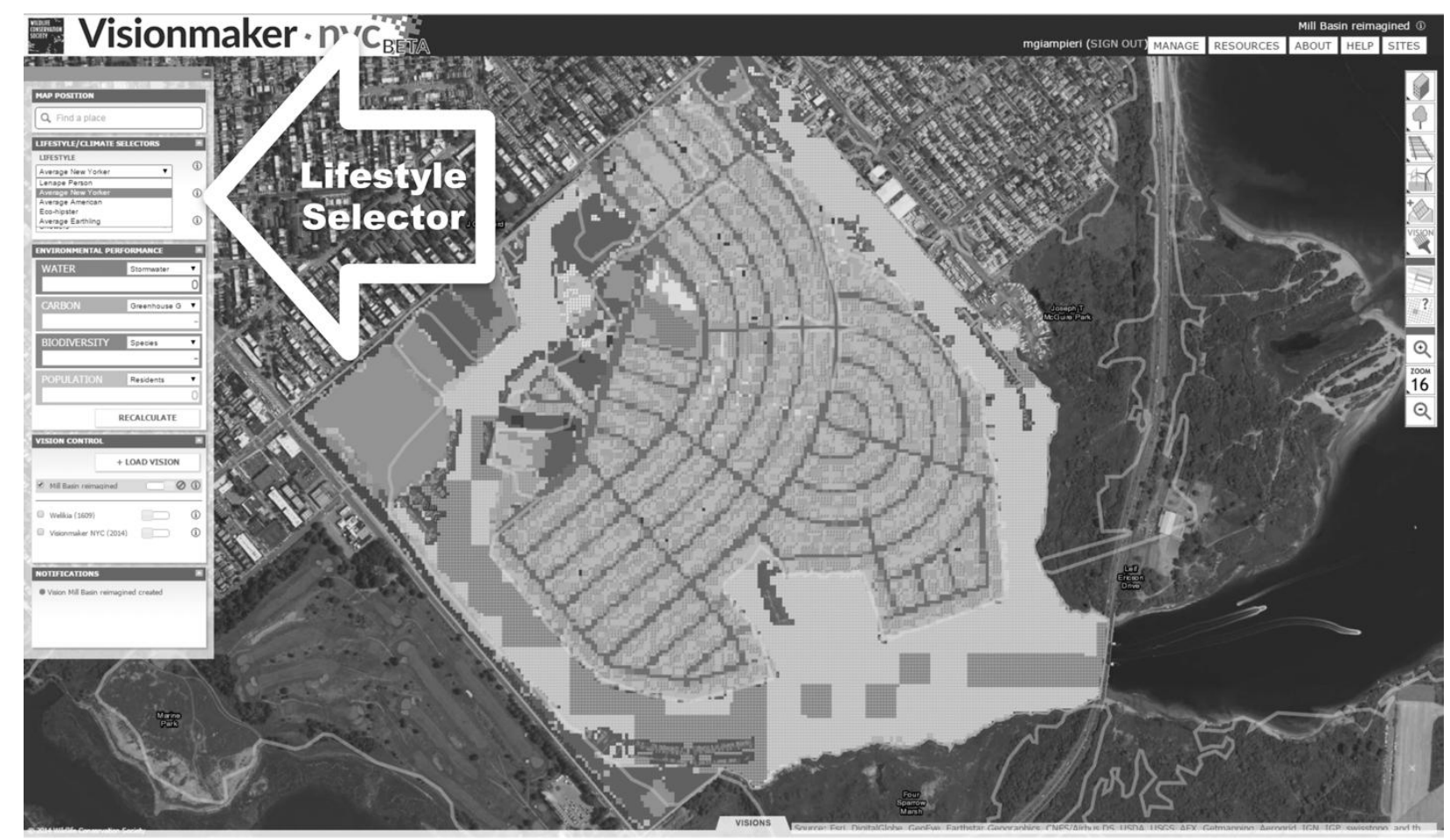

Figure 2e. 


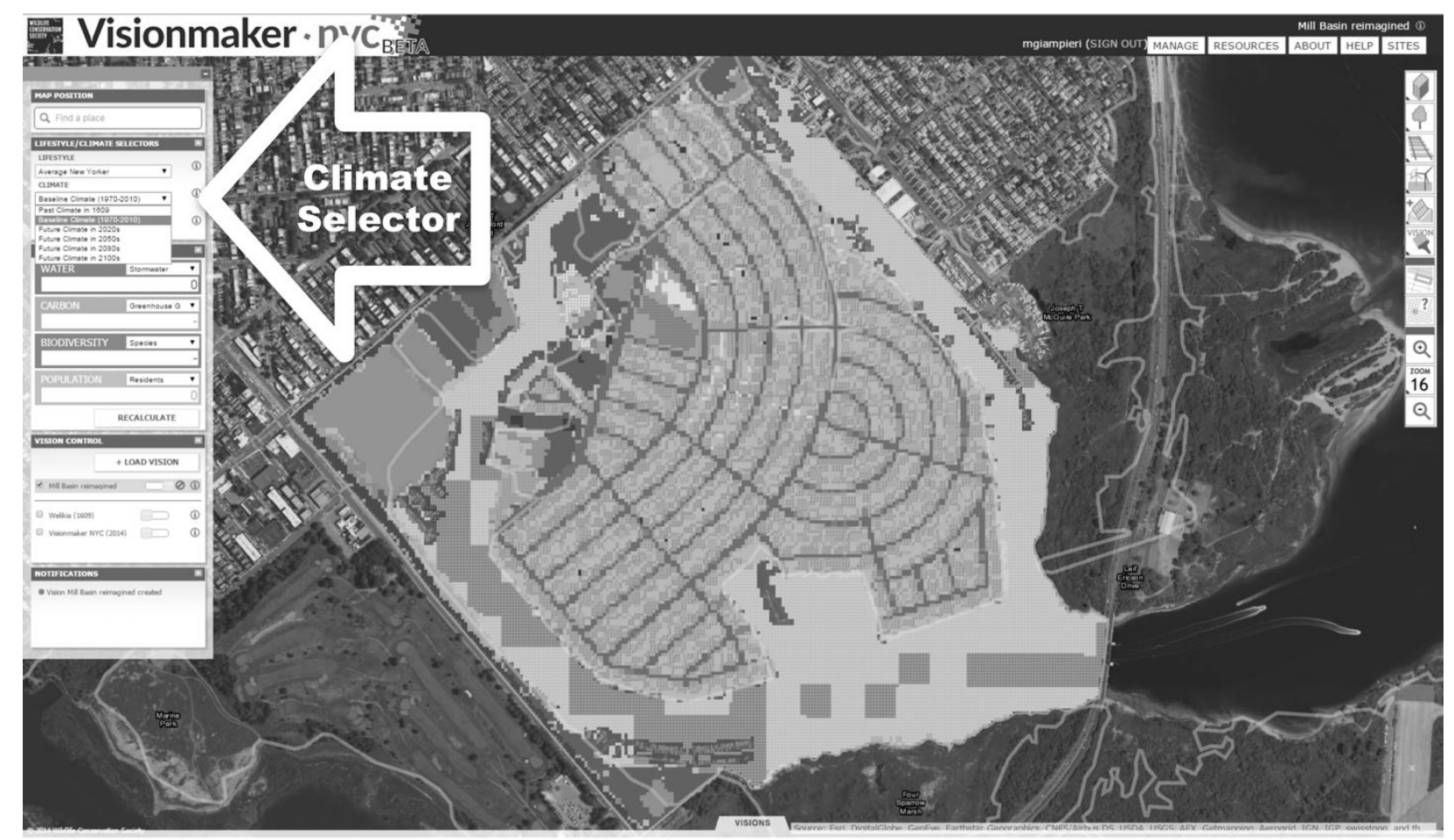

Figure $2 f$. 


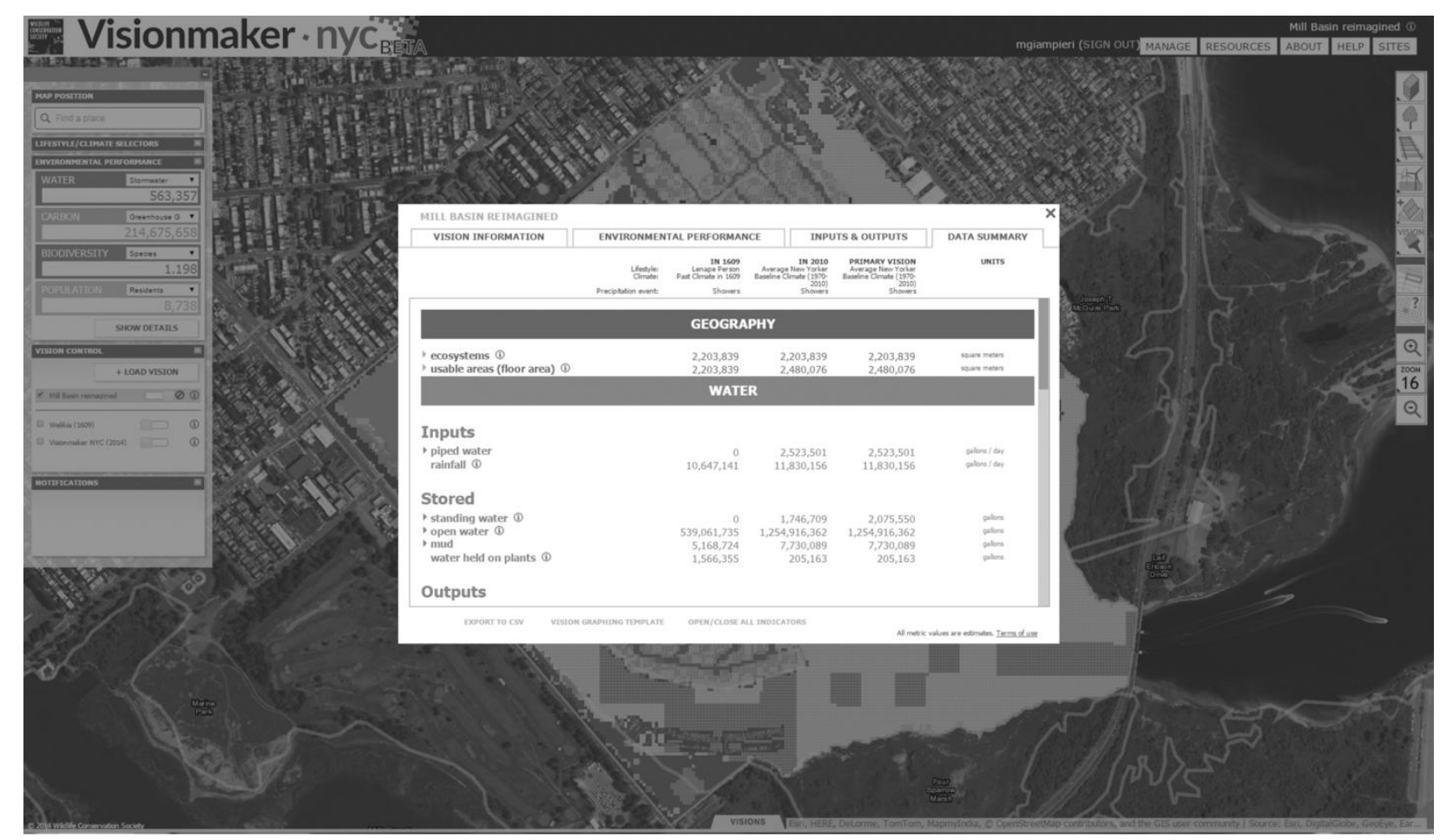


Wifi hotspot information

Name: Jonesy

Password: wildlife

If you haven't already please fill out the pre-survey before the start of the workshop: http://tiny.cc/VisionmakerJBPreSurvey 


\section{Visionmaker: Jamaica Bay}

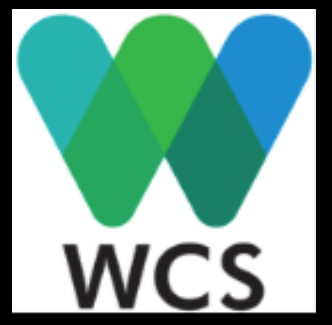

E. Sanderson, K. Fisher, M. Giampieri Wildlife Conservation Society

M. Meixler, J. Barr (RU-Newark), S. Handel. Rutgers University

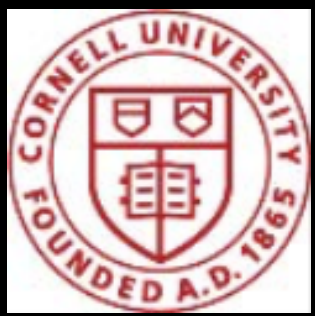

S. Allred, K. Bunting-Howarth (NY Sea Grant), B. DuBois. Cornell University 


\section{Workshop Overview}

1. Overview of the Science and Resilience Institute at Jamaica Bay (SRIJB)

2. Visionmaker: Jamaica Bay project and goals

3. Visionmaking session

4. Participant feedback and shareout of visions 


\section{Science and Resilience Institute at Jamaica Bay}

The Science and Resilience Institute at Jamaica Bay (SRI@JB) advances innovative thinking and learning about the resilience of urban coastal regions through programs of research and engagement in New York City's Jamaica Bay.

Executive Director: Adam Parris 


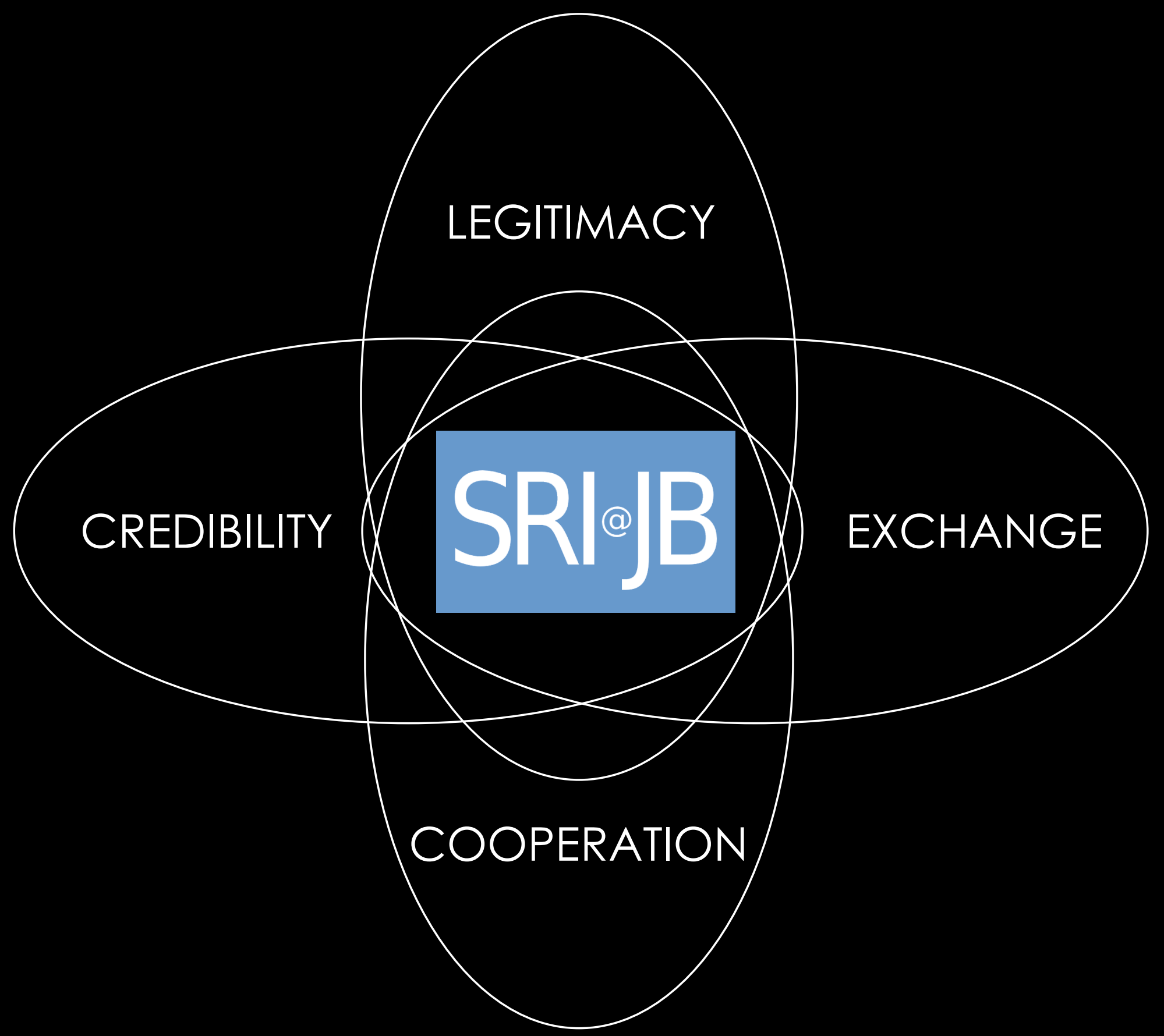




\section{Core Programs}

- Brooklyn College / CUNY (host institution)

- National Park Service

- City of New York

- The Jamaica Bay - Rockaway Parks

Conservancy

- SRI@JB Advisory Councils

- Research Consortium 


\section{Research Consortium}

- City University of New York

- Columbia University's Earth Institute and its Lamont-Doherty Earth Observatory,

- Cornell University,

- NASA Goddard Institute for Space Studies,

- New York Sea Grant,

- Institute of Marine and Coastal Sciences at Rutgers University,

- Stevens Institute of Technology,

- Stony Brook University, and

- Wildlife Conservation Society
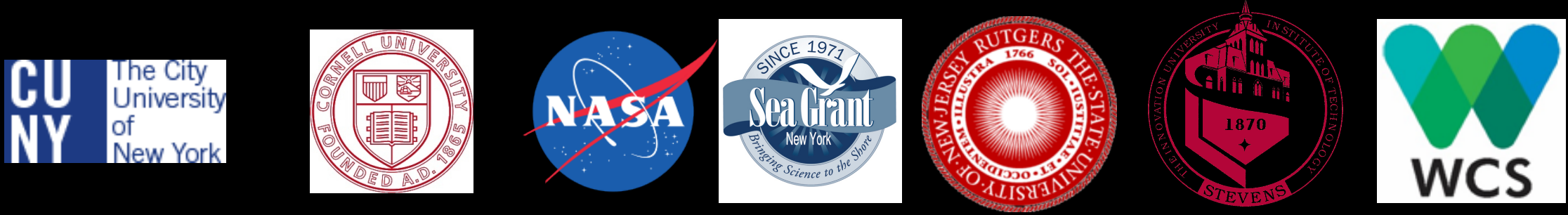

Lamont-Doherty Earth Observatory COLUMBIA UNIVERSITY|EARTH INSTITUTE 


\section{Jamaica Bay Watershed}

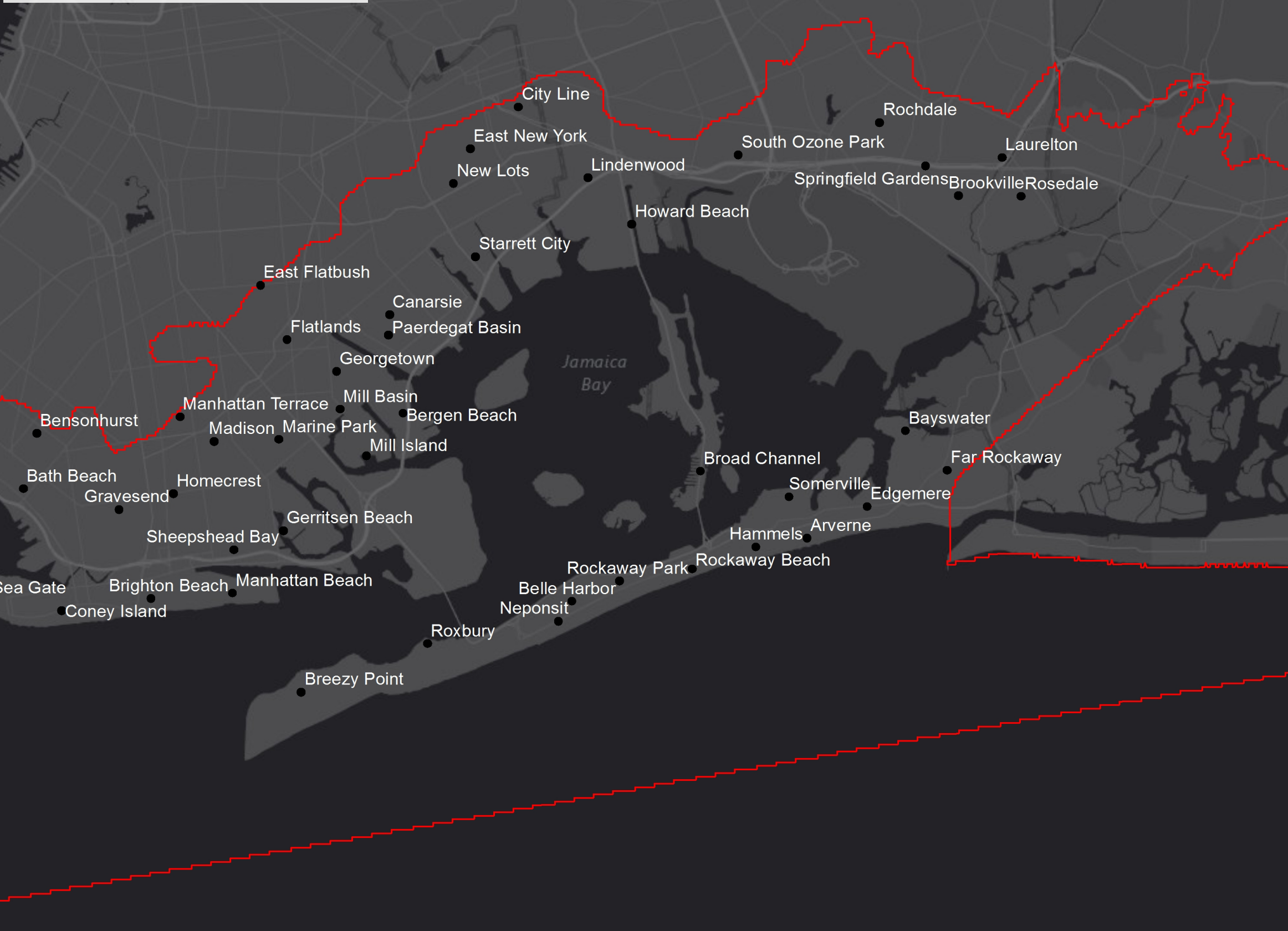




\title{
Research Approach:
}

\section{Ask representatives of different communities of practice to create visions of resilience for Jamaica Bay}

\author{
Visions are data.
}




\section{Communities of Practice}

- Non-governmental organizations (NGO)

- Public agency staff (city, state, or federal)

- Jamaica Bay Researchers

- Community Board members

- K-12 educators 


\title{
Research Question:
}

\author{
How do different \\ communities of practice
}

conceive of resilience for Jamaica Bay? 
Visionmaker video 


\section{Questions?}




\section{Visionmaking Session Instructions}

- Go to: visionmaker.nyc

- Login with your participant ID

- [first name_last name]

- Password: wildlife

- Questions? Refer to your handouts, ask us, or watch this short video:

- https://youtu.be/6q1vIQ2Jaao 


\section{Jamaica Bay Watershed}

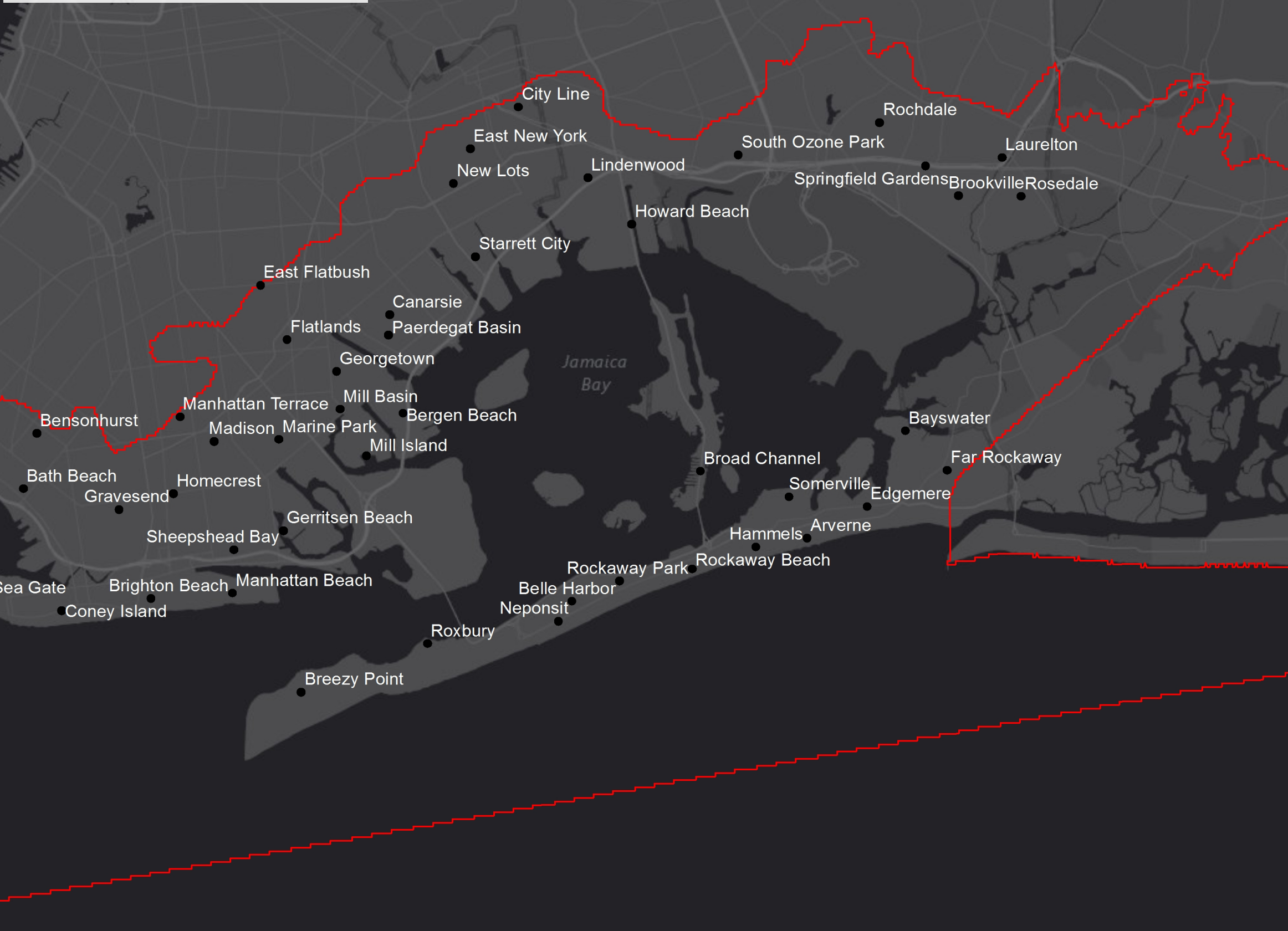


STEP 1

EXPLORE! 
STEP 2

CHOOSE A VISION EXTENT 


\section{Jamaica Bay Watershed}

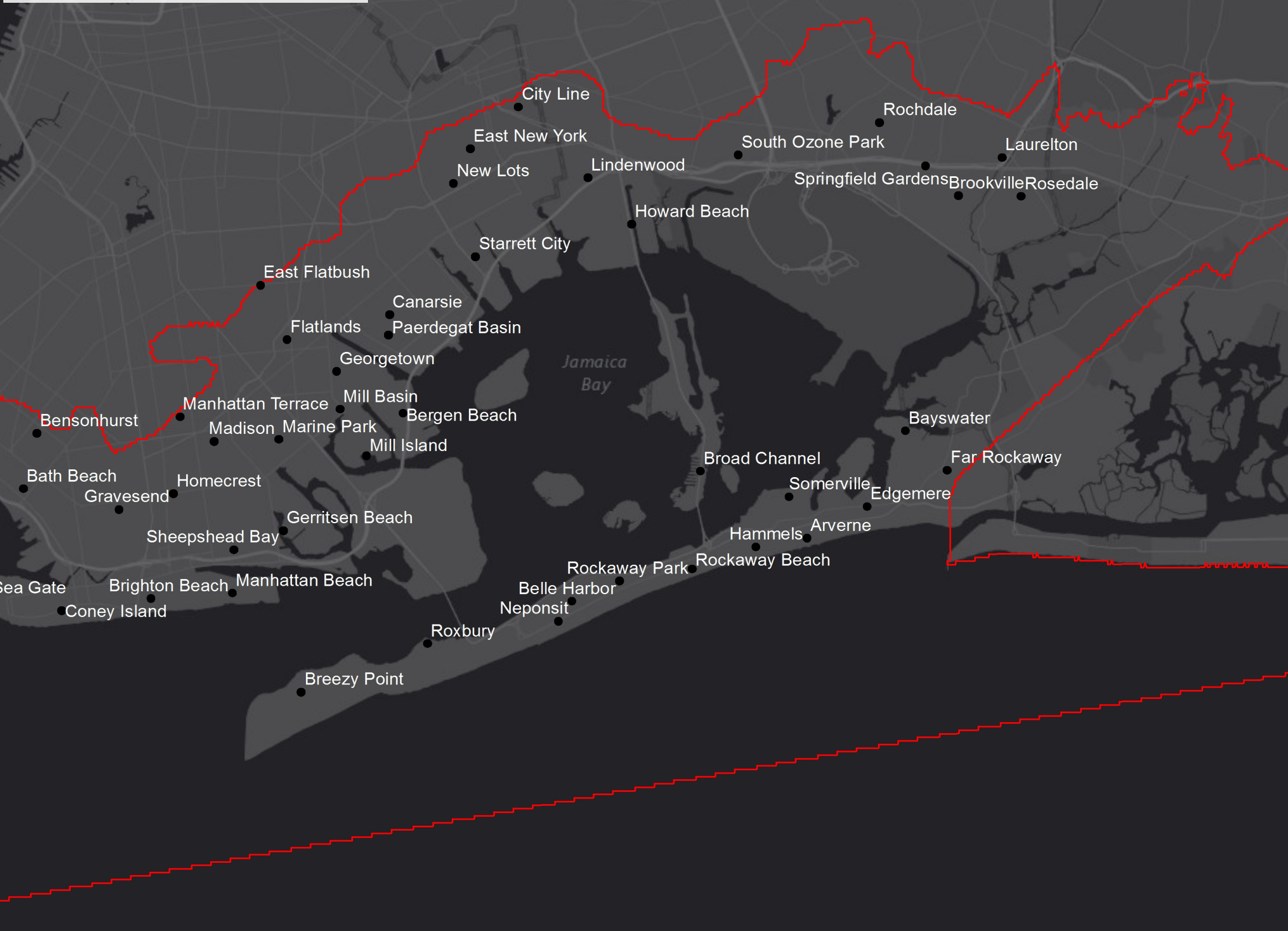


STEP 3

MANIPULATE ECOSYSTEMS 


\section{Thank you and next steps}

- Please give 24-hours before accessing vision again

- Check your email for thank you, a follow-up survey, and future events relating to this project and others with the SRI@JB 